\title{
Guidelines for the use and interpretation of assays for monitoring cell death in higher eukaryotes
}

\author{
L Galluzzi ${ }^{1,2,3}$, SA Aaronson ${ }^{4}, \mathrm{~J} \mathrm{Abrams}^{5}$, ES Alnemri ${ }^{6}$, DW Andrews ${ }^{7}$, EH Baehrecke ${ }^{8}$, NG Bazan $^{9}$, MV Blagosklonny ${ }^{10}$, \\ K Blomgren ${ }^{11,12}, \mathrm{C}$ Borner ${ }^{13}$, DE Bredesen ${ }^{14,15}, \mathrm{C}$ Brenner ${ }^{16,17}$, M Castedo ${ }^{1,2,3}$, JA Cidlowski ${ }^{18}$, A Ciechanover ${ }^{19}$, GM Cohen $^{20}$, \\ V De Laurenzii ${ }^{21}$, R De Maria ${ }^{22,23}$, M Deshmukh ${ }^{24}$, BD Dynlacht ${ }^{25}$, WS El-Deiry ${ }^{26}$, RA Flavell ${ }^{27,28}$, S Fulda ${ }^{29}$, C Garrido ${ }^{30,31}$, \\ P Golstein ${ }^{32,33,34}$, M-L Gougeon ${ }^{35}$, DR Green ${ }^{36}$, H Gronemeyer ${ }^{37,38,39}$, G Hajnóczky ${ }^{40}$, JM Hardwick ${ }^{41}$, MO Hengartner ${ }^{42}$, H Ichijo ${ }^{43}$, \\ M Jäättelä ${ }^{44}$, O Kepp ${ }^{1,2,3}$, A Kimchi ${ }^{45}$, DJ Klionsky ${ }^{46}$, RA Knight ${ }^{47}$, S Kornbluth ${ }^{48}$, S Kumar ${ }^{49}$, B Levine ${ }^{28,50}$, SA Lipton ${ }^{51,52,53,54}$, \\ E Lugli $i^{55}$, F Madeo ${ }^{56}$, W Malorni ${ }^{57}$, J-CW Marine ${ }^{58,59}$, SJ Martin ${ }^{60}$, JP Medema ${ }^{61,62}$, P Mehlen ${ }^{63,64,65}$, G Melino ${ }^{20,66}$, UM Moll ${ }^{67,68,69}$, \\ E Morselli ${ }^{1,2,3}$, S Nagata ${ }^{70}$, DW Nicholson ${ }^{71}$, P Nicotera ${ }^{20}$, G Nuñez $^{72}$, M Oren ${ }^{73}$, J Penninger ${ }^{74}$, S Pervaiz ${ }^{75,76,77}$, ME Peter ${ }^{78}$, \\ M Piacentini ${ }^{79,80}$, JHM Prehn ${ }^{81}$, H Puthalakath ${ }^{82}$, GA Rabinovich ${ }^{83}$, R Rizzuto ${ }^{84}$, CMP Rodrigues ${ }^{85}$, DC Rubinsztein ${ }^{86}$, T Rudel ${ }^{87}$, \\ L Scorrano ${ }^{88,89}$, H-U Simon ${ }^{90}$, H Steller ${ }^{28,91}$, J Tschopp ${ }^{92}$, Y Tsujimoto ${ }^{93}$, P Vandenabeele ${ }^{59,94}$, I Vitale $^{1,2,3}$, KH Vousden ${ }^{95}$, RJ Youle ${ }^{96}$, \\ J Yuan ${ }^{97}$, B Zhivotovsky ${ }^{98}$ and G Kroemer ${ }^{*, 1,2,3}$
}

Cell death is essential for a plethora of physiological processes, and its deregulation characterizes numerous human diseases. Thus, the in-depth investigation of cell death and its mechanisms constitutes a formidable challenge for fundamental and applied biomedical research, and has tremendous implications for the development of novel therapeutic strategies. It is, therefore, of utmost importance to standardize the experimental procedures that identify dying and dead cells in cell cultures and/or in tissues, from model organisms and/or humans, in healthy and/or pathological scenarios. Thus far, dozens of methods have been proposed to quantify cell death-related parameters. However, no guidelines exist regarding their use and interpretation, and nobody has thoroughly annotated the experimental settings for which each of these techniques is most appropriate. Here, we provide a nonexhaustive comparison of methods to detect cell death with apoptotic or nonapoptotic morphologies, their advantages and pitfalls. These guidelines are intended for investigators who study cell death, as well as for reviewers who need to constructively critique scientific reports that deal with cellular demise. Given the difficulties in determining the exact number of cells that have passed the point-of-no-return of the signaling cascades leading to cell death, we emphasize the importance of performing multiple, methodologically unrelated assays to quantify dying and dead cells.

Cell Death and Differentiation (2009) 16, 1093-1107; doi:10.1038/cdd.2009.44; published online 17 April 2009

\begin{abstract}
${ }^{1}$ INSERM, U848, F-94805 Villejuif, France; ${ }^{2}$ Institut Gustave Roussy, F-94805 Villejuif, France; ${ }^{3}$ Université Paris Sud-XI, F-94805 Villejuif, France; ${ }^{4}$ Department of Oncological Sciences, Mount Sinai School of Medicine, New York, NY 10029, USA; ${ }^{5}$ Department of Cell Biology, UT Southwestern Medical Center, Dallas, TX 75390 , USA; ${ }^{6}$ Department of Biochemistry and Molecular Biology, Center for Apoptosis Research, Kimmel Cancer Institute, Thomas Jefferson University, Philadelphia, PA 19107-5587, USA; ${ }^{7}$ Department of Biochemistry and Biomedical Sciences, McMaster University, L8N 3 Z5 Hamilton, Canada; ${ }^{8}$ Department of Cancer Biology, University of Massachusetts Medical School, Worcester, MA 01605-2324, USA; ${ }^{9}$ Neuroscience Center of Excellence, School of Medicine, Louisiana State University Health Sciences Center, New Orleans, LA 70112, USA; ${ }^{10}$ Roswell Park Cancer Institute, Buffalo, NY 14263, USA; ${ }^{11}$ Center for Brain Repair and Rehabilitation, Institute of Neuroscience and Physiology, University of Gothenburg, SE-405 30 Gothenburg, Sweden; ${ }^{12}$ Department of Pediatric Oncology, The Queen Silvia Children's Hospital, SE-416 85 Gothenburg, Sweden; ${ }^{13}$ Institute of Molecular Medicine and Cell Research (ZBMZ), Albert-Ludwigs-Universität Freiburg, 79104 Freiburg, Germany; ${ }^{14}$ Buck Institute for Age Research, Novato, CA 94945, USA; ${ }^{15}$ University of California - San Francisco, San Francisco, CA 94143, USA; ${ }^{16}$ University of Versailles/St Quentin, 78035 Versailles, France; ${ }^{17}$ CNRS, UMR8159, 78035 Versailles, France; ${ }^{18}$ National Institutes of Environmental Health Sciences, NIH, Duhram, NC 27709, USA; ${ }^{19}$ Vascular and Tumor Biology Research Center, The Rappaport Faculty of Medicine, Technion - Israel Institute of Technology, 31096 Haifa, Israel; ${ }^{20}$ Medical Research Council, Toxicology Unit, Leicester University, Leicester LE1 9HN, UK; ${ }^{21}$ Dipartimento di Scienze Biomediche, Università 'G. d'Annunzio' Chieti-Pescara, 66100 Chieti, Italy; ${ }^{22}$ Department of Hematology, Oncology and Molecular Medicine, Istituto Superiore di Sanità, 00161 Rome, Italy; ${ }^{23}$ Mediterranean Institute of Oncology, 95030 Catania, Italy; ${ }^{24}$ Neuroscience Center, Department of Cell and Developmental Biology, University of North Carolina, Chapel Hill, NC $27599-7250$, USA; ${ }^{25}$ Department of Pathology, New York University School of Medicine, New York, NY 10016, USA; ${ }^{26}$ Hematology-Oncology Division, University of Pennsylvania School of Medicine, Philadelphia, PA 19104, USA; ${ }^{27}$ Department of Immunobiology, Yale University School of Medicine, New Haven, CT 06520, USA; ${ }^{28}$ Howard Hughes Medical Institute, Chevy Chase, MD 20815-6789, USA; ${ }^{29}$ University Children's Hospital, 89075 Ulm, Germany; ${ }^{30}$ INSERM, UMR866, 21049 Dijon, France; ${ }^{31}$ Faculty of Medicine and Pharmacy, University of Burgundy, 21049 Dijon, France; ${ }^{32}$ INSERM, U631, 13288 Marseille, France; ${ }^{33}$ CNRS, UMR6102, 13288 Marseille, France; ${ }^{34}$ Centre d'Immunologie de Marseille-Luminy, Aix Marseille Université, 13288 Marseille, France; ${ }^{35}$ Institut Pasteur, Antiviral Immunity, Biotherapy and Vaccine Unit, 75015 Paris, France; ${ }^{36}$ Department of Immunology, St. Jude Children's Research Hospital, Memphis, TN 38105, USA; ${ }^{37}$ Department of Cancer Biology - Institut de Génétique et de Biologie Moléculaire et Cellulaire, 67404 Illkirch, France; ${ }^{38} \mathrm{CNRS}$, UMR7104, 67404 Illkirch, France; ${ }^{39}$ INSERM, U964, 67404 Illkirch, France; ${ }^{40}$ Department of Pathology, Anatomy and Cell Biology, Thomas Jefferson University, Philadelphia, PA 19107, USA; ${ }^{41}$ Department of Pharmacology and Molecular Sciences, Johns Hopkins University, Baltimore, MD 21205, USA; ${ }^{42}$ Institute of Molecular Biology, University of Zurich, 8057 Zurich, Switzerland; ${ }^{43}$ Graduate School of Pharmaceutical Sciences, University of Tokyo, Tokyo 113-0033, Japan; ${ }^{44}$ Danish Cancer Society, Department of Apoptosis, Institute of Cancer Biology, DK-2100 Copenhagen, Denmark; ${ }^{45}$ Department of Molecular Genetics, Weizmann Institute of Science, 76100 Rehovot, Israel; ${ }^{46}$ Life Sciences Institute and Department of Molecular, Cellular, and Developmental Biology and Biological Chemistry, University of Michigan, Ann Arbor, MI 48109, USA; ${ }^{47}$ Institute of Child Health, University College London, London WC1N 1EH, UK; ${ }^{48}$ Duke University School of Medicine, Durham, NC 27710, USA; ${ }^{49}$ Centre for Cancer Biology, Hanson Institute, Adelaide, South Australia 5000,
\end{abstract}


In multicellular organisms, the timely execution of programmed cell death is critical for numerous physiological processes including embryogenesis, post-embryonic development and adult tissue homeostasis. It is, therefore, not surprising that deregulated cell death is a common feature of a wide array of human diseases. On one hand, the unwarranted death of postmitotic cells constitutes one of the most important etiological determinants of acute and chronic pathologies including (but not limited to) ischemic, toxic, neurodegenerative and infectious syndromes. Conversely, disabled cell death is frequently associated with hyperproliferative conditions such as autoimmune diseases and cancer. Several well-established and experimental therapies target the molecular mechanisms of cell death, either to prevent the demise of cells that cannot be replaced, or to facilitate the elimination of supernumerary and/or ectopic cells. ${ }^{1}$ Thus, the precise characterization of the molecular machinery of cell death constitutes a major challenge for present and future research, which has already and will continue to have tremendous repercussions on the development of novel therapeutic approaches.

The first and most important question that any researcher who studies cellular demise needs to answer is: when is a cell 'dead'? Recently, the Nomenclature Committee on Cell Death (NCCD) has formulated several recommendations on the use of cell death-related terminology. ${ }^{2}$ Dying cells are engaged in a cascade of molecular events that is reversible until a first irreversible process takes place, and the 'point-of-no-return' that delimits the frontier between a cell's life and death has been trespassed. So far, a single molecular event that accounts for the point-of-no-return in the signaling cascades leading to cell death remains to be identified. Thus, the NCCD has proposed that a cell should be regarded as 'dead' when (1) the cell has lost the integrity of its plasma membrane and/ or (2) the cell, including its nucleus, has undergone complete disintegration, and/or (3) its corpse (or its fragments) has been engulfed by a neighboring cell in vivo.

In this context, another important issue is represented by the indisputable existence of numerous cell death modalities. ${ }^{2}$ Cell death represents a highly heterogeneous process that can follow the activation of distinct (although sometimes partially overlapping) biochemical cascades and can manifest with different morphological features. For instance, cells can die as they display an apoptotic morphology (which among other features is characterized by chromatin condensation,

Australia; ${ }^{50}$ Southwestern Medical Center, University of Texas, Dallas, TX 75390, USA; ${ }^{51}$ Burnham Institute for Medical Research, La Jolla, CA 92037, USA; ${ }^{52}$ The Salk Institute for Biological Studies, La Jolla, CA 92037, USA; ${ }^{33}$ The Scripps Research Institute, La Jolla, CA 92037, USA; ${ }^{54}$ Univerisity of California-San Diego, La Jolla, CA 92093, USA; ${ }^{55}$ Immunotechnology Section, Vaccine Research Center, National Institute of Allergy and Infectious Diseases, NIH, Bethesda, MD 20892, USA; ${ }^{56}$ Institute of Molecular Biosciences, University of Graz, $8010 \mathrm{Graz}$, Austria; ${ }^{57}$ Department of Therapeutic Research and Medicines Evaluation, Section of Cell Aging and Degeneration, Istituto Superiore di Sanità, 00161 Rome, Italy; ${ }^{58}$ Laboratory for Molecular Cancer Biology, VIB, 9052 Ghent, Belgium; ${ }^{59}$ Department for Molecular Biology, Ghent University, 9052 Ghent, Belgium; ${ }^{60}$ Department of Genetics, Trinity College, Dublin 2, Ireland; ${ }^{61}$ Center for Experimental and Molecular Medicine, Academic Medical Center, 1105 AZ Amsterdam, The Netherlands; ${ }^{62}$ University of Amsterdam, 1012 ZA Amsterdam, The Netherlands; ${ }^{63}$ Apoptosis, Cancer, and Development Laboratory, Centre Léon Berard, 69008 Lyon, France; ${ }^{64}$ CNRS, UMR5238, 69008 Lyon, France; ${ }^{65}$ Université de Lyon, 69008 Lyon, France; ${ }^{66}$ Department of Experimental Medicine and Biochemical Sciences, University of Rome 'Tor Vergata', 00133 Rome, Italy; ${ }^{67}$ Department of Pathology, Stony Brook University, Stony Brook, NY 11794-8691, USA; ${ }^{68}$ Department of Molecular Oncology, Göttingen Center of Molecular Biosciences, 37077 Göttingen, Germany; ${ }^{69}$ Faculty of Medicine, University of Göttingen, 37077 Göttingen, Germany; ${ }^{70}$ Department of Medical Chemistry, Graduate School of Medicine, University of Kyoto, Kyoto 606-8501, Japan; ${ }^{71}$ Merck Research Laboratories, Rahway, NJ 07065-0900, USA; ${ }^{72}$ University of Michigan Medical School, Ann Arbor, MI 48109, USA; ${ }^{73}$ Department of Molecular Cell Biology, Weizmann Institute of Science, 76100 Rehovot, Israel; ${ }^{74}$ Institute of Molecular Biotechnology of the Austrian Academy of Science, 1030 Vienna, Austria; ${ }^{75}$ Department of Physiology, Yong Loo Lin School of Medicine, Graduate School for Integrative Sciences and Engineering, National University of Singapore, 117597 Singapore; ${ }^{76}$ Singapore-MIT Alliance, National University of Singapore, 117576 Singapore; ${ }^{77}$ Duke-NUS Graduate Medical School, 169547 Singapore; ${ }^{78}$ Ben May Department for Cancer Research, University of Chicago, Chicago, IL 60637, USA; ${ }^{79}$ Laboratory of Cell Biology, National Institute for Infectious Diseases IRCCS 'L. Spallanzani', 00149 Rome, Italy; ${ }^{80}$ Department of Biology, University of Rome 'Tor Vergata', 00133 Rome, Italy; ${ }^{81}$ Department of Physiology and Medical Physics, Royal College of Surgeons in Ireland, Dublin 2, Ireland; ${ }^{2}$ Department of Biochemistry, La Trobe University, 3086 Victoria, Australia; ${ }^{83}$ Laboratorio de Inmunopatología, Instituto de Biología y Medicina Experimental (IBYME- CONICET), C1428 Buenos Aires, Argentina; ${ }^{84}$ Department of Biomedical Sciences, University of Padova, 35121 Padova, Italy; ${ }^{85}$ iMed.UL, Faculty of Pharmacy, University of Lisbon, $1649-003$ Lisbon, Portugal; ${ }^{86}$ Cambridge Institute for Medical Research, Cambridge CB2 0XY, UK; ${ }^{87}$ Biocenter, University of Würzburg, 97074 Würzburg, Germany; ${ }^{88}$ Department of Cell Physiology and Metabolism, University of Geneva Medical School, 1211 Geneva, Switzerland; ${ }^{89}$ Dulbecco-Telethon Institute, Venetian Institute of Molecular Medicine, 35129 Padova, Italy; ${ }^{90}$ Department of Pharmacology, University of Bern, 3010 Bern, Switzerland; ${ }^{11}$ Laboratory of Apoptosis and Cancer Biology, The Rockefeller University, New York, NY 10065, USA; ${ }^{92}$ Department of Biochemistry, University of Lausanne, 1066 Epalinges, Switzerland; ${ }^{93}$ Department of Medical Genetics, Osaka University Medical School, Osaka 565-0871, Japan; ${ }^{94}$ Department for Molecular Biomedical Research, VIB, 9052 Ghent, Belgium; ${ }^{95}$ The Beatson Institute for Cancer Research, Glasgow G61 1BD, UK; ${ }^{96}$ Biochemistry Section, Surgical Neurology Branch, National Institute of Neurological Disorders and Stroke, NIH, Bethesda, MD 20892, USA; ${ }^{97}$ Department of Cell Biology, Harvard Medical School, Boston, MA 02115, USA; ${ }^{98}$ Institute of Environmental Medicine, Division of Toxicology, Karolinska Institute, SE- 17177 Stockholm, Sweden

*Corresponding author: G Kroemer, INSERM, U848, Institut Gustave Roussy, PR1, 39, rue Camille Desmoulins, F-94805 Villejuif, France. Tel: + 33-1-4211-6046; Fax: + 33-1-4211-6047; E-mail: kroemer@orange.fr

Keywords: apoptosis; caspases; cytofluorometry; immunofluorescence microscopy; mitotic catastrophe; necrosis

Abbreviations: AIF, apoptosis-inducing factor; AO, acridine orange; CMXRos, chloromethyl-X-rosamine; Cyt $c$, cytochrome $c$; $\Delta \psi_{\mathrm{m}}$, mitochondrial transmembrane potential; DAPI, 4',6-diamidino-2-phenylindole; $\mathrm{DiOC}_{6}(3), 3,3^{\prime}$ dihexiloxalocarbocyanine iodide; EB, ethidium bromide; ELISA, enzyme-linked immunosorbent assay; GFP, green fluorescent protein; $\mathrm{H}_{2} \mathrm{DCFDA}, 2^{\prime}, 7^{\prime}$-dichlorodihydrofluorescein diacetate; HE, hydroethidine; HPLC, high-pressure liquid chromatography; HTS, high-

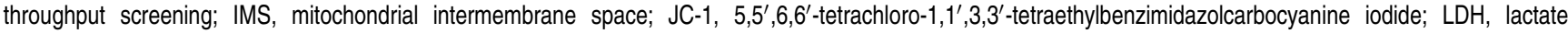
dehydrogenase; MOMP, mitochondrial outer membrane permeabilization; MPT, mitochondrial permeability transition; MS, mass spectrometry; MTS, 3-(4,5dimethylthiazol-2-yl)-5-(3-carboxymethoxyphenyl)-2-(4-sulfophenyl)-2H-tetrazolium; MTT, 3-[4,5-dimethylthiazol-2-yl]-2,5-diphenyl tetrazolium bromide; NCCD, Nomenclature Committee on Cell Death; NMP, nuclear matrix protein; NMR, proton nuclear magnetic resonance; PI, propidium iodide; TMRM, tetramethylrhodamine methyl ester; TUNEL, terminal deoxynucleotidyl transferase-mediated dUTP nick-end labeling; WST-1, 4-[3-(4-iodophenyl)-2-(4-nitrophenyl)-2H-5-tetrazolio]-1,3benzene disulfonate

Received 12.3.09; accepted 17.3.09; Edited by G Melino; published online 17.4.09 
nuclear fragmentation and overall shrinkage of the cell) or a necrotic one (which is associated with a gain in cell volume, organellar swelling and disorganized dismantling of intracellular contents). Mixed cell death morphotypes characterized by both apoptotic and necrotic traits have also been described, which has led some investigators to suggest the existence of a 'continuum' of cell death phenotypes, at least in specific experimental settings. ${ }^{3}$ Such morphological heterogeneity frequently derives from the activation of separate executioner mechanisms. Thus, beyond merely encyclopedic intents, the correct classification of cell death into specific subroutines may be extremely important for its therapeutic implications. As an example, tumor cells are often resistant to chemotherapeutic regimens that induce apoptosis, but not to necrotic triggers. In this context, the induction of one specific cell death mode (i.e., necrosis), as opposed to another (i.e., apoptosis), would result in an obvious therapeutic advantage.

The term 'autophagic cell death' has been widely employed to indicate a type of cell death that is accompanied by massive vacuolization of the cytoplasm. ${ }^{2}$ However, the relationship between autophagy and cell death remains controversial. ${ }^{4,5}$ Multiple Drosophila melanogaster developmental scenarios (including involution of salivary glands, early oogenesis and removal of the extraembryonic tissue known as amnioserosa) provide in vivo evidence that cell death can be (at least partially) executed through autophagy. ${ }^{6-9}$ Consistent with these results, the knockout/knockdown of essential autophagy (atg) genes has been shown to protect cultured mammalian cells from some lethal inducers, at least in specific experimental settings. ${ }^{10}$ Still, more frequently, pharmacological and/or genetic inhibition of autophagy does not prevent cell death, and rather accelerates it. ${ }^{11,12}$ This suggests that although cell death can occur together with autophagy, the latter likely represents a prosurvival mechanism activated by dying cells in the attempt to cope with stress. ${ }^{11,12}$ As very detailed guidelines concerning the use and interpretation of assays for monitoring autophagy have been recently provided by Klionsky and colleagues, ${ }^{13}$ this topic will not be discussed further in the present review.

Nowadays, dozens (if not hundreds) of methods are available for the detection of cell death-related parameters in vitro (in cell cultures), ex vivo (in explanted tissues and/or organs) and in vivo (in model organisms and/or humans; Figure 1). Since the beginning of cell death research, this methodological collection has been evolving, driven by the technological innovation that has characterized the last decades. However, some of the classical methods to identify dead and dying cells (e.g., light microscopy-based techniques) continue to be largely employed by researchers (due to their simplicity and/or low cost), even though they may be rather nonspecific and, therefore, inappropriate in the majority of experimental settings. Conversely, the precise quantification of a single molecular process may be excessively specific, and also result in the over- and/or underestimation of cell death. Numerous methods to detect cell death can only be applied to a limited number of experimental settings, due to intrinsic features of the model system or technical limitations of the platform on which such protocols are implemented.

Beyond obvious technical variations, the experimental procedures to identify dead and dying cells differ from one another with regard to (and hence may be classified according to) (1) specificity (i.e., some techniques selectively detect apoptosis-related phenomena, such as internucleosomal DNA cleavage, whereas others cannot discriminate between apoptotic and nonapoptotic cell death subroutines); (2) sensitivity (which is determined by the lower detection limit); (3) detection range (which relates to the upper detection limit); (4) precision (i.e., cell death-related parameters can be detected in a qualitative, semiquantitative or quantitative fashion); (5) throughput (which can be low, as for electron microscopy-based methods, standard, as for normal laboratory practices, or high, as for automated procedures); (6) cell death stage (meaning that biochemical processes belonging either to the induction/initiation, integration/decision or execution/degradation phases of the cell death cascade can be specifically quantified); (7) cell death parameter (i.e., morphological versus biochemical) or (8) readout (which can be an end-point or a real-time measurement). Concerning specificity, a clear-cut distinction has to be made between 'general' and 'cell death-type specific' techniques. Although the former (e.g., vital dyes) can detect end-stage cell death irrespective of its type (most frequently by assessing the structural dismantling of dead cells and in particular plasma membrane breakdown), the latter (e.g., caspase activation assays) monitor processes that have been specifically, yet not exclusively, associated with a particular subroutine of cell death. This hierarchical subdivision reflects the correct experimental approach that should be used when studying cell death (see also 'Concluding remarks').

Irrespective of the possible categorization of the methods to detect cell death, standardized guidelines on their use and interpretation have never been formulated. Recently, Klionsky and colleagues have approached a similar issue concerning the techniques to detect autophagy. ${ }^{13}$ Along the lines of this work, we propose here a comparison of the most common methodologies to identify and quantify dead and dying cells, with particular emphasis on their relative advantages/drawbacks and on their suitability for specific versus common experimental scenarios.

\section{Light Microscopy, Electron Microscopy and (Immuno)cyto(histo)chemistry}

Visual inspection by light microscopy provides a rapid and inexpensive means to detect cell death in a generalized and rather nonspecific fashion. This can be done on living samples (in phase contrast mode, for instance, to monitor the conditions of cultured cells), or on fixation and staining of cytospins and/or histological sections. The most common cyto(histo)chemical protocols include Papanicolaou and Mayer's hematoxylin/eosin (H\&E) stains, both of which allow the visualization of multiple intracellular structures, and in particular of the nuclei. Thus, cells displaying morphological changes that normally are associated with cell death, such as pyknotic nuclei, membrane blebbing or swollen cytoplasm can be visualized. Still, these techniques are time consuming and operator dependent, and tend to underestimate the fraction of dead/dying cells. This is due to the fact that cells in the early phases of lethal cascades usually fail to display gross morphological modifications, and hence remain undetected 


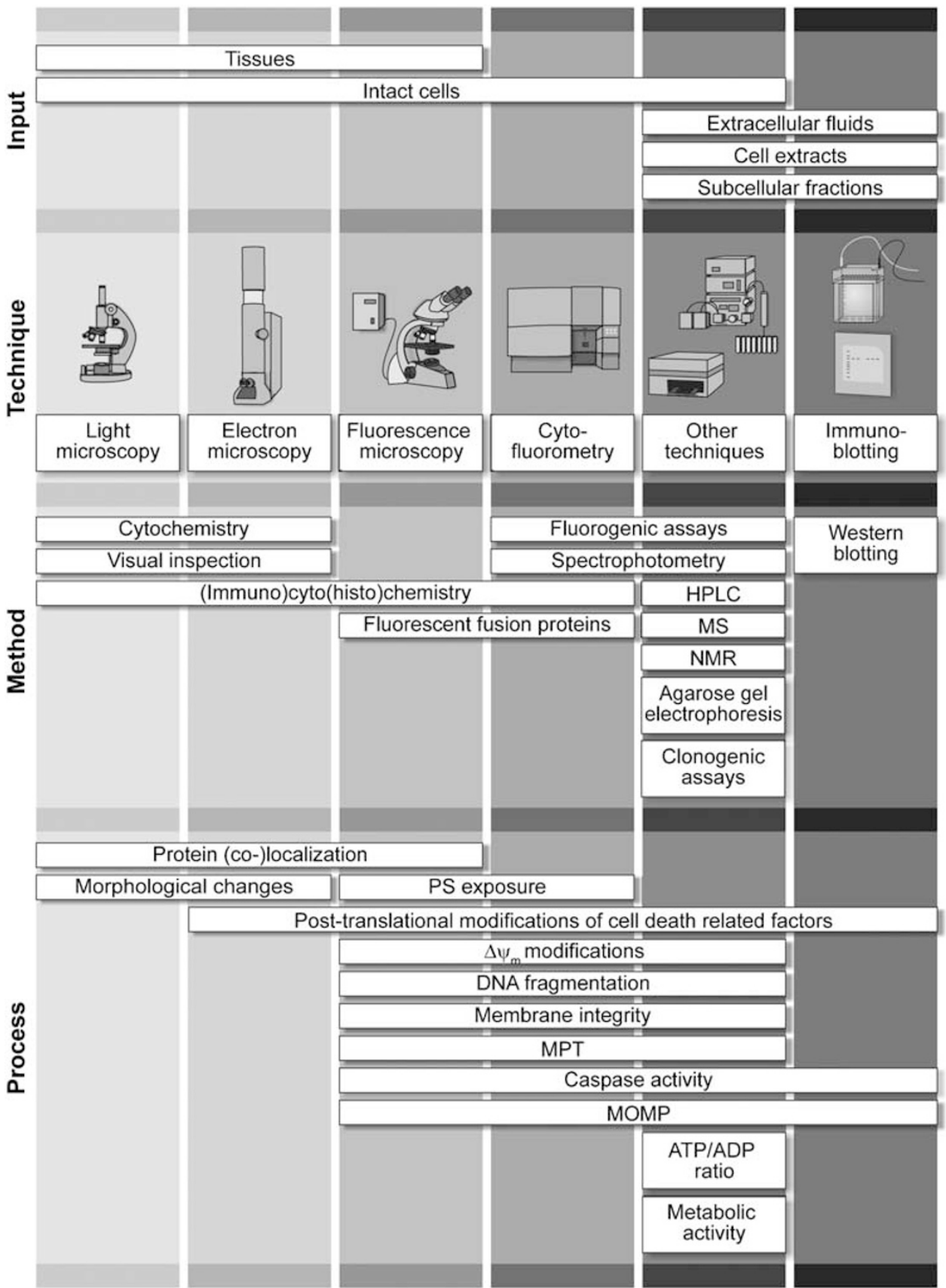

Figure 1 Methods to detect cell death-related variables. Nowadays, a cornucopia of techniques is available to monitor cell death-related parameters. Within this 'methodological abundance/redundancy', the choice of the most appropriate techniques and the correct interpretation of results are critical for the success of any study dealing with cell death. Here, the most common procedures to detect dead/dying cells are indicated, together with the technical platforms that are required for their execution and the types of specimens on which they can be applied. Please see the main text for further details. $\Delta \psi_{\mathrm{m}}$, mitochondrial transmembrane potential; HPLC, high-pressure liquid chromatography; MOMP, mitochondrial outer membrane permeabilization; MPT, mitochondrial permeability transition; MS, mass spectrometry; NMR, nuclear magnetic resonance; PS, phosphatidylserine; SDS-PAGE, sodium dodecyl sulfate-polyacrylamide gel electrophoresis

by these approaches. Similarly, light microscopy-based techniques fail to recognize completely disintegrated cells, whose fragments are too small to be seen. These sources of underestimation can be partially overcome by video or time-lapse microscopy, allowing for the cumulative scoring of cell death throughout the entire duration of experiments. Moreover, when the fraction of dead cells is low (as it is often the case in vivo), it may be difficult for the operator to perceive them within the normal tissue architecture (for instance in histological sections). In this context, the use of vital dyes (i.e., dyes that selectively stain either live or dead cells), such as trypan blue or crystal violet, is advantageous in that it limits underestimation, by allowing the identification of dead cells that have not yet undergone significant structural 
modifications. Although exclusion dyes (i.e., vital dyes that cannot enter or are actively extruded by healthy cells, yet are taken up by cells with permeabilized plasma membranes) provide a very simple means to estimate the amount of live (and hence dead) cells in counting chambers, light microscopy-based techniques are inappropriate for highthroughput applications. However, visual inspection by light microscopy can be useful to follow the degenerative changes that are associated with the death of postmitotic cells over time (e.g., neurons, cardiomyocytes and myotubes). Indeed, as these cells do not replicate, they cannot be studied by methods that require a large number of cells (e.g., cytofluorometry) nor by techniques that are based on proliferation (e.g., clonogenic assays; see below).

(Immuno)cyto(histo)chemistry protocols coupled with light microscopy allow for the quantification (in cytospins or histological sections) of cells characterized by some (but not all) of the biochemical changes associated with cell death. This applies, for instance, to caspase activation or PARP-1 proteolytic processing, and in general to all molecular processes that can be detected by specific primary antibodies, including activation-dependent accumulation (e.g., p53), overexpression (e.g., Puma); cleavage (e.g., procaspases; caspase substrates), phosphorylation/dephosphorylation (e.g., p53, p38 ${ }^{\mathrm{MAPK}}$ ), conformational changes (e.g., Bax; Bak) and other posttranslational modifications (e.g., acetylation, sumoylation). Secondary antibodies coupled to horseradish peroxidase or to alkaline phosphatase can be revealed with chromogenic substrates, and positive cells display a brownish-blackish color, which is readily detectable, for instance over an H\&E background. Less prone to underestimation than biochemical stains (and hence more suitable for quantitative applications), (immuno)cyto(histo)chemistry protocols are also advantageous because they allow for the detection of early cell death-related events, such as the cleavage of initiator caspases. Still, these methods heavily depend on the performance (background, specificity) of the primary antibody of choice, and are limited to low levels of throughput.

One classical application of cyto(histo)chemistry is the detection of DNA fragmentation by the terminal deoxynucleotidyl transferase-mediated dUTP nick-end labeling (TUNEL) method. ${ }^{14}$ This technique is characterized by higher sensitivity than most other cyto(histo)chemical approaches and has long been considered to be the gold standard to detect apoptosis in situ. However, TUNEL false positivity may result from necrotic cell death (at least in some cases), as well as from inappropriate processing of samples, which may occur - for example - during sectioning. ${ }^{15}$ For these reasons, although in many cases (and in particular in some disease models) ${ }^{16}$ TUNEL remains the only method for investigating apoptosis in situ, whenever possible, researchers should include appropriate positive and negative controls and should corroborate the results of TUNEL by at least one independent experimental approach.

Electron microscopy permits the visualization of fine ultrastructural modifications that accompany cell death, including gaps in the plasma and/or in the mitochondrial outer membrane, ${ }^{17}$ mitochondrial swelling ${ }^{18}$ and the first phases of chromatin condensation (which only later become visible by light microscopy). ${ }^{19}$ Although electron microscopy can provide an impressive amount of ultrastructural information, the visual inspection of electron microphotographs should always be complemented by a robust quantitative approach. Indeed, as the analysis is conducted on a per-cell basis and only a fraction of cells within each sample can be studied, this is critical for researchers to avoid focusing their investigation on rare (or even artefactual) morphologies. Moreover, sample processing/staining for electron microscopy is very laborious and requires trained personnel. Nevertheless, immunoelectron microscopy procedures can provide very detailed insights into the molecular mechanisms of cell death. As an example, the use of secondary antibodies coupled to gold particles of different sizes has been successfully employed to precisely visualize the colocalization of Bax with Bid and VDAC-1 in apoptotic human tumor cells. ${ }^{20}$ Thus, although electron microscopy cannot be used for routine determinations, it is nearly irreplaceable for the ultrastructural analysis of some processes linked to cell death.

Table 1 summarizes the advantages and pitfalls of light microscopy, electron microscopy and (immuno)cyto(histo)chemistry applied to cell death research.

\section{(Immuno)fluorescence Microscopy and Immunoblotting}

Nearly all (immuno)cyto(histo)chemical protocols can be transposed to fluorescence microscopy approaches, with a number of significant advantages. First, fluorescence generally (but not always, see below) ensures a higher signal-to-noise ratio than chromogenic techniques, which improves sensitivity. Second, the detection method does not involve an enzymatic reaction, whose efficacy may be perturbed by several variables including buffer composition, $\mathrm{pH}$ and temperature. Third, secondary antibodies coupled to fluorochromes with distinct absorption/emission spectra are compatible with sophisticated costaining protocols, which permits the routine detection of three to four distinct cell deathrelated events at the same time. Fourth, fluorescent dyes and fluorescent fusion proteins can be employed in combination with immunological methods, further extending the parameters that can be monitored at the same time. Finally, confocal (but not conventional) immunofluorescence microscopy enables 3D reconstitution of samples, which may be useful for colocalization experiments (see below for a note of caution).

The most common applications of (immuno)fluorescence microscopy for cell death research include, but are not limited to (1) quantification of viable cells by the calcein retention technique; ${ }^{21,22}$ (2) highly specific detection of apoptotic cells in live tissue and embryos (from model organisms as diverse as $D$. melanogaster, Xenopus leavis, zebrafish and mice) with acridine orange (AO); ${ }^{23-25}$ (3) identification of live, apoptotic and necrotic cells on acridine orange/ethidium bromide ( $\mathrm{AO} /$ EB) staining; ${ }^{26}$ (4) visualization of nuclear condensation with Hoechst 33342 or $4^{\prime}, 6$-diamidino-2-phenylindole (DAPI); ${ }^{27}$ (5) TUNEL, performed with fluorochrome-coupled streptavidin to recognize biotinylated dUTP; ${ }^{28}$ (6) stable mitochondrial staining (for colocalization experiments, see below) with fixable $\Delta \psi_{\mathrm{m}}$-sensitive dyes (e.g., chloromethyl-X-rosamine, CMXRos); ${ }^{29}$ (7) real-time monitoring of the $\Delta \psi_{\mathrm{m}}$ in living 


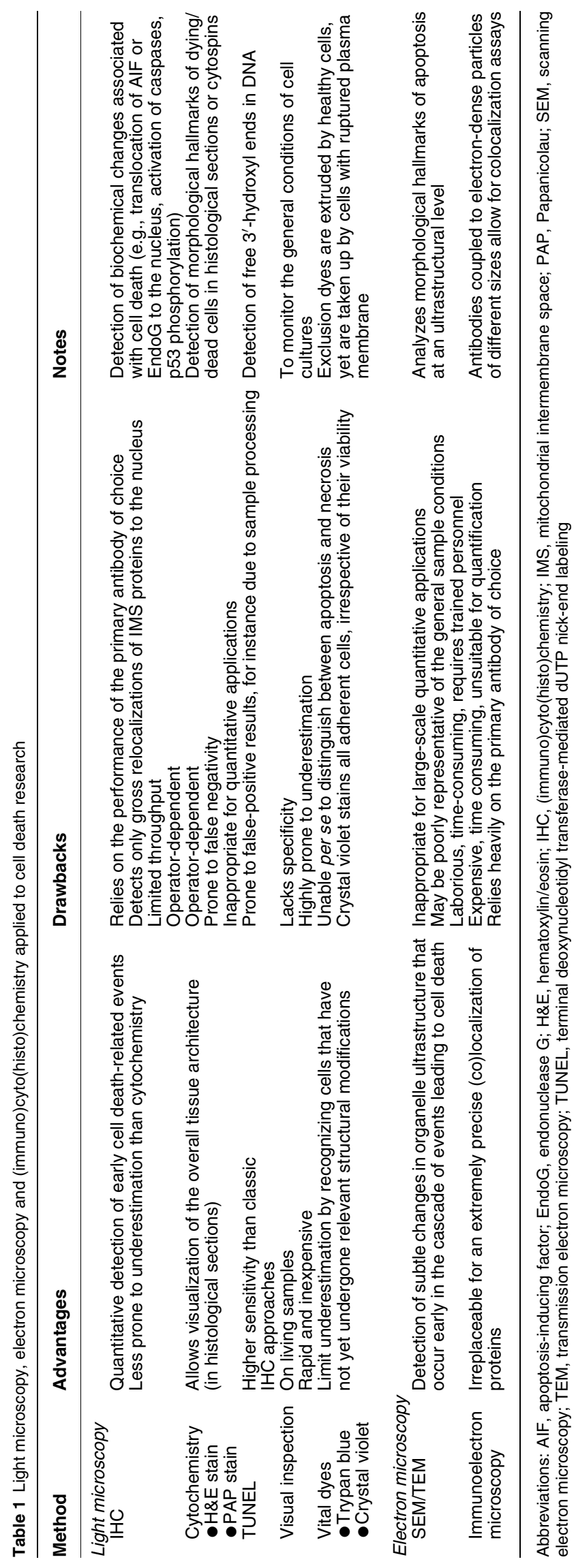

cells via nontoxic $\Delta \psi_{\mathrm{m}}$-sensitive fluorochromes (e.g., $5,5^{\prime}$, 6,6'-tetrachloro-1,1',3,3'-tetraethylbenzimidazolcarbocyanine iodide, JC-1; tetramethylrhodamine methyl ester, TMRM); ;6,30 (8) quantification of cells characterized by massive caspase activation; ${ }^{19}$ (9) detection of the so-called mitochondrial permeability transition (MPT) via the calcein quenching method; ${ }^{31}(10)$ analysis of the mitochondrial relocalization of proapoptotic proteins from the Bcl-2 family (e.g., Bax, $\mathrm{Bid}){ }^{32,33}$ (11) detection of the cytosolic spillage of lysosomal proteins (e.g., cathepsin proteases), ${ }^{34,35}$ which is indicative of lysosomal membrane permeabilization (LMP); ${ }^{36}(12)$ monitoring of the mitochondrio-cytosolic (or mitochondrio-nuclear) translocation of mitochondrial intermembrane space (IMS) proteins (e.g., cytochrome $c$ (Cyt $c$ ), apoptosis-inducing factor (AIF)). ${ }^{37-39}$ Notably, relocalization studies can be performed as end-point measurements by indirect immunofluorescence staining, ${ }^{40}$ and also in real time by video or time-lapse microscopy of living cells that have been engineered to express constitutive, inducible or photoactivatable green fluorescent protein (GFP)-tagged proteins. ${ }^{32,33,41-43}$

Until recently, visual quantification of cells characterized by one or more cell death-related parameters was required to obtain quantitative data from (immuno)fluorescence microscopy-based techniques, which represented one of their most relevant weaknesses. Fortunately, this has begun to change with the progressive dissemination of high-throughput workstations that allow for automated image acquisition from 96-well plates and software-assisted image analysis. In some cell types, autofluorescence (which results in a very poor signal-to-noise ratio) greatly restricts the usefulness of fluorescence-based (as opposed to chromogenic) detection. Moreover, as compared to (immuno)cyto(histo)chemistry, (immuno)fluorescence microscopy is intrinsically limited in that it does not allow for the simultaneous observation of labeled and unlabeled structures. This might be particularly relevant for histological studies, which often involve the visual inspection of overall tissue architecture. At least partially, this drawback can be circumvented by the sequential acquisition (from the same field) of each fluorescent signal as well as of the bright and/or dark field, followed by software-assisted image reconstitution.

Finally, to avoid common misinterpretations of immunofluorescence microscopy-derived results, it should always be remembered that (1) protein-to-protein colocalization does not necessarily mean protein-to-protein physical/functional interaction; (2) colocalization assays require confocal microscopes (which, as opposed to conventional microscopes) can acquire images from distinct $z$ planes); (3) due to physical constraints, the resolution of such instruments along the $z$ axis is significantly worse than along the $x$ and $y$ axes, and never lower than $350 \mathrm{~nm}$ and (4) to compensate for limited Zresolution, 3D reconstruction software is generally based on extrapolation algorithms. For all these reasons, confocal immunofluorescence microscopy is appropriate to determine rather gross colocalizations (e.g., between a protein and a subcellular compartment), but cannot replace immunoelectron microscopy for extremely precise spatial determinations, nor coimmunoprecipitation assays to ascertain protein-toprotein physical interactions.

Immunoblotting (alone or combined with immunoprecipitation) has also been widely employed for qualitative and/or 
semiquantitative analysis of cell death-related phenomena, including (de)phosphorylation-dependent activation of cell death regulators (e.g., p53, Bcl-2), ${ }^{44,45}$ conformational changes in proapoptotic Bcl-2 protein family members (e.g., Bax, Bak), ${ }^{46,47}$ caspase activation (by employing either monoclonal antibodies specific for active caspases or antisera that recognize both the processed and proenzymatic caspase form), ${ }^{47}$ cleavage of caspase substrates (e.g., cytokeratin 18 ,

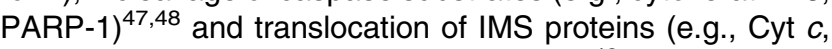
AIF) to extramitochondrial compartments. ${ }^{49}$ In contrast to immunofluorescence microscopy-based methods, immunoblotting allows the study of subcellular fractions, and in particular the analysis of the release of IMS proteins from purified mitochondria. ${ }^{39}$ Nonetheless, immunoblotting protocols are time consuming, unsuitable for large-scale applications and provide reliable semiquantitative results only when primary antibodies are employed at subsaturating concentrations. Moreover, although fluorescence-based detection ensures enhanced sensitivity as compared to classical chemiluminescence, the detection of small and/or weakly expressed proteins may be difficult to achieve and/or require prolonged optimization. Finally, it should be kept in mind that although (immuno)fluorescence microscopy-based quantifications are performed on a per-cell basis, semiquantitative immunoblotting data represent whole cell populations, irrespective of any intrapopulation, intercell heterogeneity. Thus, immunoblotting is not ideal for the analysis of heterogeneous cell samples such as primary tissues or solid tumors.

In Table 2, the benefits and disadvantages of (immuno)fluorescence microscopy- and immunoblotting-based methods to monitor cell death are illustrated.

\section{Cytofluorometry and Luminometry}

The most convenient technique to study cell death on a per-cell basis is cytofluorometry. To this aim, dozens of protocols have been optimized, for instance based on (1) cell-permeant probes with different functional properties (e.g., 3,3'dihexiloxalocarbocyanine iodide $\left(\mathrm{DiOC}_{6}(3)\right), \mathrm{JC}-1$ or TMRM, to measure $\Delta \psi_{m}$; calcein, to monitor MPT) ${ }^{50,51}$ (2) plasma membrane-impermeant fluorochromes, used as exclusion dyes (e.g., DAPI; propidium iodide (PI)); ${ }^{52}$ (3) fluorochrome-coupled secondary antibodies, for indirect immunostaining procedures (which can detect nearly all processes that can be visualized by immunofluorescence microscopy, see above); (4) chromatinophilic dyes, to quantify

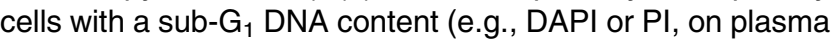
membrane permeabilization; Hoechst 33342$){ }^{53}$ (5) fluorochrome-coupled Annexin V, to detect the exposure of phosphatidylserine (PS) on the outer leaflet of the plasma membrane, ${ }^{54}$ (6) fluorogenic caspase or cathepsin substrates $^{55,56}$ or (7) oxidative stress-sensitive probes (e.g., $2^{\prime}, 7^{\prime}$-dichlorodihydrofluorescein diacetate $\left(\mathrm{H}_{2} \mathrm{DCFDA}\right)$, hydroethidine (HE)). ${ }^{40,57}$ Moreover, cytofluorometry has been employed to detect the morphological modifications that characterize apoptosis (i.e., cell shrinkage and augmented granularity of the intracellular content), the changes in morphology and $\Delta \psi_{\mathrm{m}}$ dissipation of purified mitochondria undergoing MPT in vitro, ${ }^{58,59}$ as well as a readout for TUNEL.
The detection of light scattering and up to 10 different fluorescent signals allows for the simultaneous yet independent analysis of 10-12 distinct parameters on living or fixed cell suspensions. In this context, it is critical to remember that not all protocols for cytofluorometry are compatible with each other, and hence can be combined into a single multiparametric study. This relates to the possible overlap between emission spectra from distinct fluorochromes, and also to sample processing. As an example, protocols that require plasma membrane permeabilization (e.g., assessment of the cell cycle distribution with chromatinophilic fluorochromes, quantification of intracellular antigens by indirect immunostaining) are inherently incompatible with methods based on intact cells (e.g., incorporation of exclusion dyes, Annexin V-mediated detection of PS exposure).

In contrast to (immuno)fluorescence microscopy-based methods, cytofluorometric techniques provide quantitative results independently from visual quantification of 'positive' events, which limits operator-dependent bias, and allows for the rapid acquisition of 10000-100000 events per sample, resulting in increased statistical power and higher throughput. The recent introduction of 96-well plate cytofluorometers will further augment the applicability of these approaches to high-throughput screening (HTS) procedures. Still, the need for a large number of cells makes cytofluorometry inappropriate for the study of primary (and in particular postmitotic) cell cultures. Moreover, as cytofluorometric methods require cell-to-cell dissociation, they are intrinsically unsuitable for the direct study of histological sections. Fluorogenic caspase substrates are prone to unspecific degradation, both in cells and in cell lysates, which may lead to false-positive results. In this context, the use of caspase inhibitors can help in determining the caspase-specific signal. Finally, as a caveat to the use of PS exposure alone as a marker of early apoptosis, it should be noted that (1) if plasma membranes are permeabilized (as during late apoptosis or early necrosis) Annexin $\mathrm{V}$ can bind to intracellular PS; (2) PS exposure can prepare cells for phagocytic removal independently of apoptosis ${ }^{60}$ and that (3) PS exposure can be compromised in cells in which autophagy is impaired. ${ }^{61}$

Luminometry has been primarily applied to cell death research for the quantification of intracellular bioenergetic stores, based on reports suggesting that the ATP/ADP ratio can be used to discriminate between apoptosis, necrosis and arrested proliferation. ${ }^{62}$ Luminometry-based techniques are extremely sensitive (due to a nearly undetectable background) and 96-well plate luminometers are widely available. However, ATP and ADP levels are rapidly affected by extracellular and/or intracellular perturbations, and hence cannot be used alone (without further validation by complementary tests) for the detection of a complex phenomenon such as cell death. As an example, nutrient depletion often results in a significant consumption of ATP that is not followed by cell death, due to the activation of the autophagic pathway. ${ }^{63}$

Table 3 summarizes the advantages and drawbacks of cytofluorometry and luminometry-based methods for the study of cell death. 


Method
(Immuno)fluorescence microscopy
AO staining

AO staining

AO/EB staining

Calcein retention

Calcein quenching

Caspase activation assays

$\psi_{m}$-sensitive fluorochromes

Fixable (e.g., CMXRos)

TMRM)

Nuclear counterstaining

DAPI

Relocalization

IMS proteins (e.g., AIF, Cyt $c$ )

Proapoptotic Bcl-2 proteins

(e.g., Bax, Bid)

Lysosomal proteins

Posttranslational (in)activation (e.g., Bax, p53)

TUNEL

Immunoblotting

Caspase activation assays

Release of IMS proteins from mitochondria (e.g., AlF, Cyt $c$ )

Posttranslational (in)activation (e.g., Bax, p53)

\section{Advantages}

Allows for the highly specific identification of apoptotic cells in live tissues and embryos from various model organisms

Very rapid and simple

Allows for the discrimination among live, (early and late) apoptotic and necrotic cells

Suitable for both proliferating and nonproliferating cells Higher signal-to-noise ratio than other fluorochromes

Allows for the visualization of mitochondria with an intact IM Suitable for videomicroscopy

Quantitative analysis on a per-cell basis (as opposed to IB) The cleavage of cell-permeant, fluorogenic substrates can

Allow for the visualization of energized mitochondria

No need for permeabilization Nonfixable probes allow for real-time monitoring of $\Delta \psi_{m}$

Labeling is rapid

Useful to clearly identify nuclei in colocalization assays Hoechst 33342 is cell permeant

No need for subcellular fractionation (as opposed to IB) Indicative of the subcellular localization of IMS protein upon mitochondrial release

Fusion proteins allow for real-time (video or time-lapse microscopy-based) studies

Quantitative analysis on a per-cell basis (as opposed to IB) Detects early biochemical events in cell death cascades

Useful in costaining protocols, to confirm DNA fragmentation

Applicable to subcellular fractions (as opposed to IF or cytofluorometry)

Based on standard laboratory equipment

Allows for the study of subcellular fractions and purified mitochondria (as opposed to IF)

Allows the monitoring of early biochemical events of the cell death cascade

\section{Drawbacks}

AO undergoes photobleaching after several seconds Stained tissues must be observed and photographed immediately

EB is carcinogenic

Some expertise may be required to clearly distinguish

between late apoptotic and necrotic cells

Diluted calcein-AM must be used immediately after

preparation, as it spontaneously hydrolyzes

Calcein is actively extruded by MDR1-overexpressing cells

Reversible permeabilization of the IM leads to the loss of calcein signal in the absence of MPT

erator dependent

Cespative-activation may occur in cell deathelate

Immunostainings heavily depend on the performance of priman an be partially

作 s, and this may be hard to differentiate from

versible loss

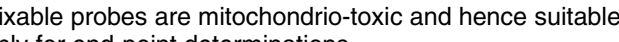

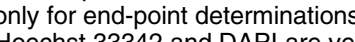

Dery sensitive to

photobleaching Inappropriate on its own to conveniently

monitor cell death

Require confocal microscopy

At least two IMS proteins should be evaluated, to exclude

artifacts

Two-color colocalization approaches are required (with sessile mark

organelles)

Opsuitable for very prer

Specific conform

Prone to false-positive results, for instance due to sample processing

Semiquantitative (the analysis involves entire cell

Small protein fragments (such as degradation products) may be difficult to detect

Time-consuming

Not suitable for large-scale or high-throughput application May require a significant amount of starting material

Relies on conformation- or neoepitope-specific antibodies Specific conformations may be unstable and get lost during
purification or electrophoresis
Notes

The elevated specificity of $\mathrm{AO}$ for apoptotic cells within live tissues and embryos is still not fully understood AO stains both live and dead cells, while EB is taken up only by cells that have los plasma membrane integrity

Cell-permeant, nonfluorescent calcein AM is hydrolyzed by IC esterases to calcein, which is fluorescent and retaine by viable cells

Detects the loss of barrier function of the IM to ions (in particular to $\mathrm{Co}^{2+}$ )

Based on antibodies that recognize activ caspases or cleaved substrates

Cationic lipophilic probes accumulate in mitochondria driven by the $\Delta \psi_{m}$

metric dyes (e.g., JC-1) change

emission spectra as a function of $\Delta \psi_{m}$

Nuclear pyknosis is a classical hallmark of apoptotic cells

MOMP is monitored by assessing the subcellular relocalization of IMS proteins The translocation and full insertion into the OM of Bax mediates MOMP

LMP leads to the cytosolic spillage of cathepsins, which are able to induce MMP Analysis of structural changes in cell death regulators

Detection of free $3^{\prime}$-hydroxyl ends in DNA

Based on antibodies that recognize active caspases, their cleaved substrates or both the inactive and active forms of caspases

MOMP is monitored by assessing the presence of IMS proteins in nonmitochondrial subcellular fractions Analysis of structural changes in cell death regulators

Abbreviations: AIF, apoptosis-inducing factor; AM, acetomethoxy; AO, acridine orange; CMXRos, chloromethyl-X-rosamine; Cyt $c$, cytochrome $c ; \Delta \psi_{\mathrm{m}}$, mitochondrial transmembrane potential; DAPI, 4',6-diamidino2-phenylindole; EB, ethidium bromide; IB, immunoblotting; IC, intracellular; IF, (immuno)fluorescence microscopy; IM, mitochondrial inner membrane; IMS, mitochondrial intermembrane space; JC-1, $5,5^{\prime}, 6,6^{\prime}$-tetrachloro-1,1',3,3'-tetraethylbenzimidazolcarbocyanine iodide; LMP, lysosomal membrane permeabilization; OM, mitochondrial outer membrane; MDR1, multidrug resistance protein 1; MOMP, mitochondrial outer membrane permeabilization; MPT, mitochondria permeability transition; TMRM, tetramethylrhodamine methyl ester; TUNEL, terminal deoxynucleotidyl transferase-mediated dUTP nick-end labeling 
Table 3 Cytofluorometric and luminometric techniques to monitor cell death-related variables

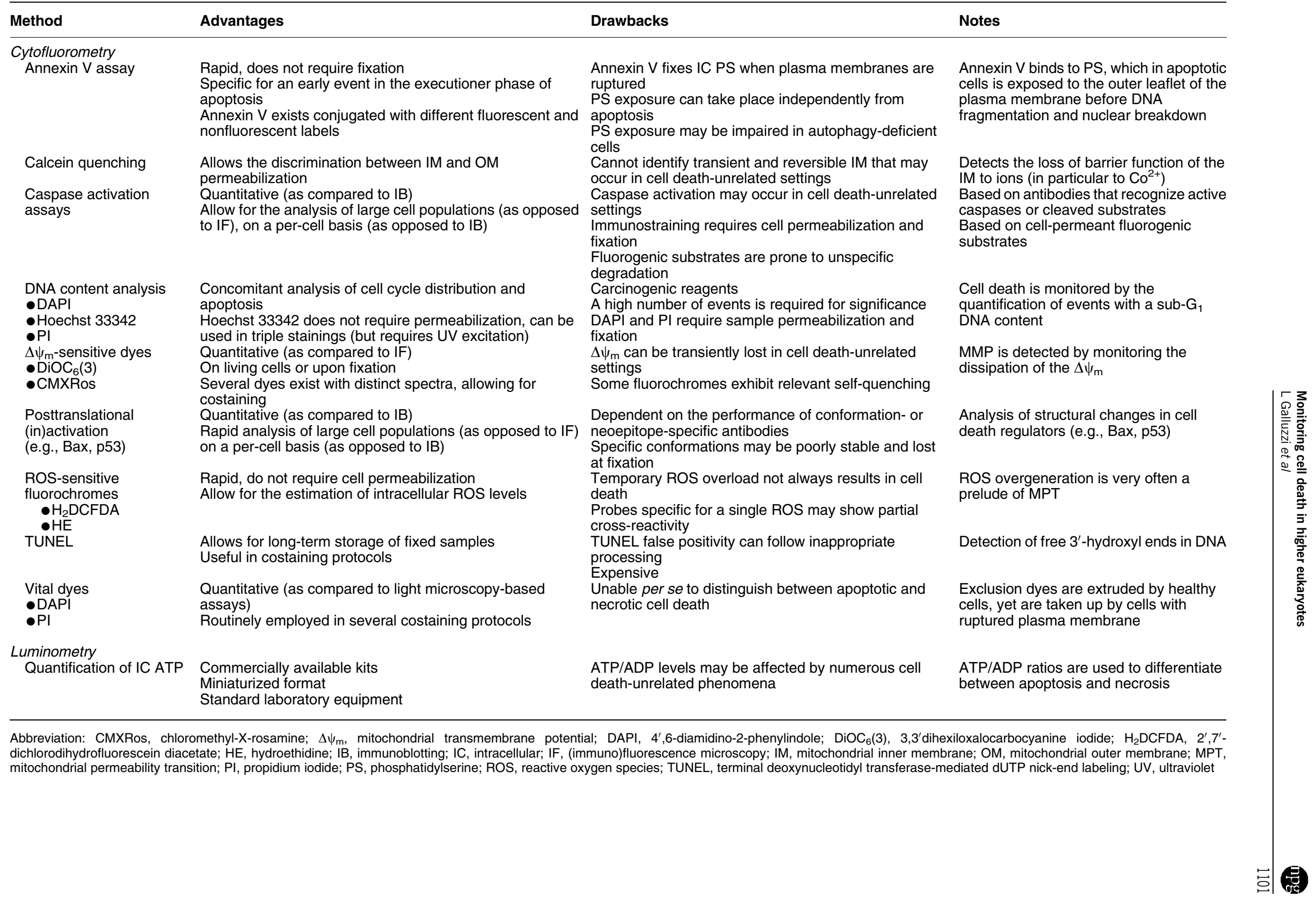




\section{Spectrophotometry}

Due to the fact that they are fairly suitable for automation (and hence adaptable to high-throughput procedures), numerous 96-well plate-based methods are used to study cell deathrelated parameters. For instance, plasma membrane breakdown (as a sign of cytotoxicity) can be detected by assessing culture supernatants for the activity of enzymes that are normally confined within the cell (e.g., lactate dehydrogenase $(\mathrm{LDH}))^{47}$ Moreover, the activity of the mitochondrial respiratory chain is widely considered as an indicator of the number of viable cells, and hence measured to study cell death versus proliferation. To this aim, the most common protocols involve membrane-permeant colorless tetrazolium salts, which can be administered to living cells and are converted by metabolically active mitochondria into colored products. ${ }^{19,47,64}$ The widely employed, first-generation tetrazolium derivative 3-[4,5-dimethylthiazol-2-yl]-2,5-diphenyl tetrazolium bromide (MTT) is reduced by mitochondrial dehydrogenases to formazan, which is water-insoluble and hence accumulates in cytosolic crystals. As a consequence, the spectrophotometric quantification of formazan requires cell lysis and overnight solubilization of crystals, which - however - are cytotoxic even in small amounts. Thus, MTT conversion can only be employed in the context of endpoint determinations. As opposed to MTT, second-generation tetrazolium derivatives (e.g., 3-(4,5-dimethylthiazol-2-yl)-5(3-carboxymethoxyphenyl)-2-(4-sulfophenyl)-2H-tetrazolium (MTS) or 4-[3-(4-iodophenyl)-2-(4-nitrophenyl)-2H-5-tetrazolio]1,3-benzene disulfonate (WST-1)) are metabolized into nontoxic, water-soluble, membrane-permeant products, which freely diffuse in the culture supernatant. Thus, MTS and WST-1 do not compromise the viability of cultures, thereby being compatible with recurring and/or real-time determinations.

Both LDH release and MTT/MTS/WST-1 conversion are commonly employed for cell death research, presumably because (1) they allow for the simultaneous analysis of a large number of specimens; (2) they are rapid and do not require preprocessing of samples (e.g., cell lysis); (3) they do not need specialized laboratory equipment; (4) ready-made kits are available, which often include appropriate controls and (5) they are fairly economical (as compared to immunological techniques). Nevertheless, both LDH release and MTT/MTS/ WST-1 tests suffer from considerable drawbacks. For instance, the release of LDH cannot be used for discriminating among distinct cell death modalities. Moreover, this test measures an enzymatic activity, which tends to decrease with time as a result of natural degradation, and can be affected by several variables, including $\mathrm{pH}$ as well as the presence of specific components in the culture medium. The conversion of MTT/MTS/WST-1 by mitochondrial enzymes may reflect metabolic alterations that do not necessarily correlate with the number of viable cells. Medium overconsumption and/or excessive cell density are two very common situations that result in a pronounced shutdown of mitochondrial functions. In these conditions, the use of an MTT/MTS/WST-1-based test alone would lead to the underestimation of the number of living cells. In summary, the use of these colorimetric methods is advisable only for the preliminary phase of a cell death study, when hundreds to thousands of conditions have to be screened, and only as long as relevant controls are included. In this context, a valuable approach would be to integrate these assays with one another, allowing for the crossconfirmation of the cytotoxicity and proliferation datasets.

Several kits based on the enzyme-linked immunosorbent assay (ELISA) principle are available to measure cell deathrelated parameters in cell culture supernatants, intact cells, subcellular fractions, tissue extracts or body fluids. ELISAbased assessments have been optimized to monitor phenomena as different as Cyt $c$ release, caspase-3 activation, release of intracellular proteins following plasma membrane breakdown, presence of dissociated nucleosomes due to chromatin fragmentation, and expression on the cell surface of death receptors and/or their ligands, for instance. Nearly all these methods can be implemented on 96-well plates, allowing for quantification by standard laboratory spectrophotometers, and they are often characterized by increased sensitivity. Depending on the specific process that is monitored, some of these protocols may require laborious preprocessing of samples, which in turn limits throughput. As an example, ELISA-based kits that quantify Cyt $c$ release require subcellular fractionation, and hence provide few/no advantages as compared to immunofluorescence microscopy or cytofluorometry. ${ }^{27}$ Still, miniaturized assays of this kind are well adapted for the precise quantification of cell death-related factors released in the culture medium or in body fluids by dead/dying cells (e.g., nuclear matrix protein (NMP)), ${ }^{65}$ which usually requires no/limited preprocessing. In this context, two interesting applications are represented by the detection of cytoplasmic versus extracellular histone-associated DNA fragments, ${ }^{66}$ and of caspase-cleaved versus full-length cytokeratin 18 in extracellular fluids, ${ }^{67,68}$ because they can provide an estimation of apoptotic versus nonapoptotic cell death. For the correct interpretation of this kind of quantitative data - however - it should be noted that all ELISA-detectable markers decay (perhaps with the exception of caspasecleaved cytokeratin 18), due to both enzymatic and nonenzymatic reactions. This precludes any quantitative correlation between the concentration of a given marker and the percentage of dead/dying cells, which in turn makes these assays not ideal for cell death research.

Spectrophotometry has often been used to monitor MPT in vitro, on mitochondria purified from cell cultures or rodent organs and resuspended in sucrose media. Under these conditions, MPT leads to an abrupt increase in the volume of the mitochondrial matrix (known as 'large amplitude swelling'), which can be followed by measuring the absorbance of the mitochondrial suspension at $545 \mathrm{~nm}$. This method has been successfully implemented on 96-well plates, which can be monitored by standard laboratory spectrophotometers. ${ }^{27}$ As most of these instruments are able to simultaneously measure several types of signal (e.g., absorbance, fluorescence, luminescence), swelling measurements can be combined with additional tests (e.g., calcein quenching assays, $\Delta \psi_{\mathrm{m}}{ }^{-}$ sensitive dyes, $\mathrm{Ca}^{2+}$-sensitive probes) in the context of a multiparametric analysis. ${ }^{69,70}$ Moreover, the use of pure mitochondrial suspensions enables investigators to define a specific experimental microenvironment, and hence is essentially irreplaceable for studying the direct induction of MPT 
by a given molecule in the absence of metabolic interference. For the same reasons, this technique cannot be used to investigate the effect of molecules that act on mitochondria by indirect mechanisms, for instance via metabolic intermediates or by activating intracellular signaling pathways. Finally, large amplitude swelling is not easily exploitable in high throughput applications for at least two reasons. First, such applications would require a large amount of mitochondria, in turn demanding either the killing/postmortem processing of dozens of rodents at the same time or the simultaneous culture and subcellular fractionation of billions of cells. Second, in energized buffers in vitro, mitochondria retain their structural and functional integrity only for a limited time (4-6h).

In Table 4, spectrophotometric methods for monitoring cell death are compared based on their advantages and pitfalls.

\section{Other Techniques}

Clonogenic assays constitute a technique of choice to determine the long-term fate of proliferating cells, because they can identify an irreversible arrest of cell growth occurring so late that it would go undetected by other methods. ${ }^{71}$ Although clonogenic assays cannot differentiate between cell demise and senescence (which is not a form of cell death), ${ }^{2}$ they represent the gold standard method to study the cytotoxic versus cytostatic effects of anticancer agents. The long-term fate of senescent cells has not yet been precisely determined, and may considerably fluctuate in distinct experimental settings. Most likely, with time, senescent cells activate a hitherto unidentified signaling cascade that eventually ensures their disposal. However, as loss of clonogenicity does not necessarily derive from cell demise ${ }^{2}$ clonogenic assays are intrinsically not ideal to study 'pure' cell death.

DNA agarose gel electrophoresis followed by EB staining has represented a cornerstone method to discriminate between apoptotic, internucleosomal DNA fragmentation (resulting in the so-called 'DNA ladder', whose 'rungs' are represented by DNA fragments of $180 \mathrm{bp}$ and multiples thereof) and necrotic, nonspecific DNA degradation (resulting in a 'smear' of randomly degraded DNA). ${ }^{72}$ Although less laborious than protein electrophoresis, this method (as opposed to immunoblotting) is being increasingly disregarded due to the existence of cost-effective alternatives that monitor the same process, such as TUNEL. In spite of the fact that agarose gel electrophoresis is less prone to false positivity than TUNEL and that noncarcinogenic nonradioactive stains provide a safe alternative to ethidium bromide, nowadays this technique is rarely used in cell death research.

One recently developed technological platform, known as ImageStream, allows for the simultaneous acquisition of both overall fluorescence and of several microphotographs (in either bright-field, dark-field or fluorescence imaging mode) from each flowing cell. This instrument, which combines the visual resolution of (immuno)fluorescence microscopy with the statistical power of cytofluorometry, is being increasingly applied to cell death research. As an example, unique combinations of photometric and morphometric measures, as acquired by the ImageStream cytofluorometer in a single run, have been used to discriminate among live, (early and late) apoptotic and necrotic cells. ${ }^{73}$ It can be anticipated that several other techniques to quantify cell death-related parameters will be implemented on this technological platform during the next few years.

Additional protocols to detect cell death-related parameters rely on nuclear magnetic resonance (NMR), high-pressure liquid chromatography (HPLC) and mass spectrometry (MS). For instance, the NMR properties of the structured water (i.e., bound to macromolecules) within mitochondria have been exploited to discriminate among MOMP, MPT and more complex scenarios (such as those affecting mitochondria in vivo) ${ }^{74}$ HPLC has been used to quantify the release of Cyt $c$ from purified rat liver mitochondria, which is more rapid and ensures higher sensitivity than ELISA- or immunoblottingbased methods. ${ }^{75}$ Proteomic approaches based on subcellular fractionation followed by MS analysis have been used in multiple cell death-related settings, including the identification of proteins released by mitochondria undergoing MPT, ${ }^{76}$ or of proteins that are exposed on the plasma membrane surface of apoptotic cells. ${ }^{77}$ These techniques, and in particular MSbased proteomic studies, provide a large amount of experimental data, which allows for the in-depth investigation of cell death-related phenomena. However, they are suboptimal for routine determinations, because each requires a sophisticated technology, qualified personnel and a nonnegligible phase of optimization for every experimental protocol.

Table 5 presents the benefits and drawbacks of additional techniques applied to cell death research.

\section{Concluding Remarks}

Dozens of methods exist to measure cell death-related parameters, which depend on distinct technologies and which can be distinguished with regard to their specificity, sensitivity, detection range, precision and throughput. Each of these techniques was originally developed for a specific purpose, and some have evolved toward more general applicability. Thus, a cornucopia of protocols is available for the study of cell death. Nevertheless, none of these methods is sufficient per se to unambiguously demonstrate cell death, and a combination of complementary yet unrelated techniques should always be employed (see below). Such a methodological profusion may result (and has indeed too often resulted) in the use of assays that are completely inappropriate for the experimental setting under investigation. Both authors and reviewers must be blamed for the publication of papers in which cytotoxic and/or cytoprotective effects have been erroneously described, due to the use of inappropriate methods. Thus, in multiple instances, caspase activation has been (mis)interpreted as an unequivocal sign of apoptotic cell death when it is known that caspases also participate in many processes not linked to cellular demise. ${ }^{78}$ This common mistake can now be avoided thanks to the increasing knowledge on the specific substrates that are cleaved by caspases during cell death but not in cell death-unrelated scenarios. ${ }^{79}$ As an example, in erythroblasts, the transcription factor GATA-1 is cleaved by caspase-3 on death receptor engagement, ${ }^{80}$ yet it remains uncleaved when caspase- 3 is activated during erythroid differentiation. ${ }^{81}$

No guidelines will ever address in a specific fashion each experimental scenario related to cellular demise. Thus, to 
Table 4 Spectrophotometry applied to cell death research

\begin{tabular}{|c|c|c|c|}
\hline Method & Advantages & Drawbacks & Notes \\
\hline \multicolumn{4}{|l|}{ ELISA-based methods } \\
\hline $\begin{array}{l}\text { Caspase activation } \\
\text { assays }\end{array}$ & $\begin{array}{l}\text { Based on standard laboratory equipment } \\
\text { Quantitative data on the presence of active caspases }\end{array}$ & $\begin{array}{l}\text { Requires cell lysis or the use of cell-free fluids } \\
\text { (e.g., plasma) } \\
\text { Caspase activation may occur in cell death-unrelated } \\
\text { settings }\end{array}$ & $\begin{array}{l}\text { Based on antibodies that specifically } \\
\text { recognize the active fragments of } \\
\text { caspases }\end{array}$ \\
\hline $\begin{array}{l}\text { Chromatin fragmentation } \\
\text { tests }\end{array}$ & $\begin{array}{l}\text { Largely more sensitive than agarose gel electrophoresis } \\
\text { Detection of cytoplasmic versus EC nucleosomes allows } \\
\text { for the estimation of apoptotic versus nonapoptotic cell } \\
\text { death }\end{array}$ & $\begin{array}{l}\text { Standardization is required to obtain reliable results } \\
\text { Antibodies in some commercial kits do not fix } \\
\text { nucleosomes from all human cell types } \\
\text { May require fractionation }\end{array}$ & $\begin{array}{l}\text { Based on the quantification of dissociated } \\
\text { nucleosomes released from the } \\
\text { chromatin of dying cells (in the cytosol } \\
\text { and/or in EC fluids) }\end{array}$ \\
\hline $\begin{array}{l}\text { Cytokeratin } 18 \text { cleavage } \\
\text { and release assays }\end{array}$ & $\begin{array}{l}\text { Provides a means to estimate the proportion of apoptotic } \\
\text { versus nonapoptotic cell death in vivo }\end{array}$ & $\begin{array}{l}\text { Limited to cytokeratin 18-expressing (epithelial) cells } \\
\text { Each sample requires two distinct ELISA-based } \\
\text { assessments }\end{array}$ & $\begin{array}{l}\text { Based on the detection in EC fluids of } \\
\text { caspase-cleaved versus full-length } \\
\text { cytokeratin } 18\end{array}$ \\
\hline $\begin{array}{l}\text { Expression of death } \\
\text { receptors and/or ligands }\end{array}$ & $\begin{array}{l}\text { Crude and/or impure samples can be used without } \\
\text { affecting binding selectivity }\end{array}$ & $\begin{array}{l}\text { Augmented expression of death receptors and/or of } \\
\text { their ligands may not necessarily result in increased } \\
\text { cell death }\end{array}$ & $\begin{array}{l}\text { Used to detect the presence of death } \\
\text { receptors and/or of their ligands at the } \\
\text { surface of cells or within body fluids }\end{array}$ \\
\hline $\begin{array}{l}\text { Release of IC proteins } \\
\text { into EC fluids (e.g., NMP) }\end{array}$ & $\begin{array}{l}\text { Allows for the identification of cytostatic versus cytotoxic } \\
\text { effects } \\
\text { No need for laborious sample preprocessing }\end{array}$ & $\begin{array}{l}\text { Released proteins decay due to both enzymatic and } \\
\text { nonenzymatic reactions that normally occur in EC fluids }\end{array}$ & $\begin{array}{l}\text { IC proteins in culture supernatants and/or } \\
\text { body fluids indicate plasma membrane } \\
\text { breakdown }\end{array}$ \\
\hline $\begin{array}{l}\text { Release of IMS proteins } \\
\text { from mitochondria } \\
\text { (e.g., AlF, Cyt } c \text { ) }\end{array}$ & $\begin{array}{l}\text { High sensitivity (as compared to IF and IB) } \\
\text { Provides precise quantitative data }\end{array}$ & $\begin{array}{l}\text { Subcellular fractionation required } \\
\text { Stringent need for analytical standardization }\end{array}$ & $\begin{array}{l}\text { Based on the detection of IMS proteins in } \\
\text { distinct subcellular compartments }\end{array}$ \\
\hline \multicolumn{4}{|c|}{ Others } \\
\hline Large amplitude swelling & $\begin{array}{l}\text { Allows the study of MPT in vitro, in mitochondria purified } \\
\text { from rodent liver or cell cultures } \\
\text { Permits excluding the activity of metabolic intermediates/ } \\
\text { products } \\
\text { Basic laboratory equipment }\end{array}$ & $\begin{array}{l}\text { Dependent on the purity of the mitochondrial } \\
\text { suspension } \\
\text { Purified mitochondria are stable for a limited time frame } \\
\text { Unsuitable for large-scale or high-throughput } \\
\text { applications }\end{array}$ & $\begin{array}{l}\text { Mitochondria undergoing MPT swell, and } \\
\text { this leads to a decrease in absorbance }\end{array}$ \\
\hline LDH release assays & $\begin{array}{l}\text { Relatively inexpensive (as compared to ELISA-based } \\
\text { tests) } \\
\text { Based on standard laboratory equipment and rapid } \\
\text { Appropriate for the first rounds of high-throughput studies }\end{array}$ & $\begin{array}{l}\text { Cannot discriminate between distinct subroutines of } \\
\text { cell death } \\
\text { LDH stability in supernatants and body fluids as well } \\
\text { as its enzymatic activity can be affected by several } \\
\text { factors }\end{array}$ & $\begin{array}{l}\text { Detects by colorimetric means the } \\
\text { enzymatic activity of LDH released by } \\
\text { dead cells (in culture supernatants or } \\
\text { body fluids) }\end{array}$ \\
\hline $\begin{array}{l}\text { Tetrazolium salt } \\
\text { conversion assays } \\
\text { (e.g., MTT, MTS, WST-1) }\end{array}$ & $\begin{array}{l}\text { Relatively inexpensive (as compared to ELISA-based } \\
\text { tests) } \\
\text { Based on standard laboratory equipment and rapid } \\
\text { MTS and WST- } 1 \text { can be used for real-time determinations } \\
\text { Appropriate for the first rounds of high-throughput studies }\end{array}$ & $\begin{array}{l}\text { Mitochondrial activity may be shut down in cell } \\
\text { death-unrelated settings (e.g., overconfluence) } \\
\text { MTT is converted to cytotoxic, water-insoluble } \\
\text { formazan } \\
\text { Require some optimization, since conversion efficiency } \\
\text { differs in distinct cell lines }\end{array}$ & $\begin{array}{l}\text { The conversion of a cell-permeant, } \\
\text { colorless salt of tetrazolium by } \\
\text { mitochondrial dehydrogenases is } \\
\text { employed as an indicator of viable cells }\end{array}$ \\
\hline
\end{tabular}

Abbreviations: AIF, apoptosis-inducing factor; Cyt $c$, cytochrome $c$; EC, extracellular; ELISA, enzyme-linked immunosorbent assay; IB, immunoblotting; IC, intracellular; IF, (immuno)fluorescence microscopy; LDH, lactate dehydrogenase; MPT, mitochondrial permeability transition; MTS, 3-(4,5-dimethylthiazol-2-yl)-5-(3-carboxymethoxyphenyl)-2-(4-sulfophenyl)-2H-tetrazolium; MTT, 3-[4,5-dimethylthiazol-2-yl]-2,5-diphenyl tetrazolium bromide; NMP, nuclear matrix protein; WST-1, 4-[3-(4-iodophenyl)-2-(4-nitrophenyl)-2H-5-terazolio]-1,3-benzene disulfonate 
Table 5 Other techniques to detect cell death-related phenomena

\begin{tabular}{|c|c|c|c|}
\hline Method & Advantages & Drawbacks & Notes \\
\hline $\begin{array}{l}\text { Agarose gel } \\
\text { electrophoresis }\end{array}$ & $\begin{array}{l}\text { Allows for the discrimination between } \\
\text { apoptotic versus nonapoptotic instances } \\
\text { of cell death }\end{array}$ & $\begin{array}{l}\text { Requires DNA isolation } \\
\text { Inappropriate for large-scale applications } \\
\text { Detection often based on carcinogenic } \\
\text { dyes }\end{array}$ & $\begin{array}{l}\text { Internucleosomal DNA } \\
\text { fragmentation results in the } \\
\text { so-called DNA ladder }\end{array}$ \\
\hline $\begin{array}{l}\text { Caspase } \\
\text { activation } \\
\text { assays }\end{array}$ & $\begin{array}{l}\text { Miniaturized } \\
\text { Allows for large-scale and high-throughput } \\
\text { applications } \\
\text { Standard laboratory equipment } \\
\text { (multi-well fluorescence reader) }\end{array}$ & $\begin{array}{l}\text { Caspase activation may occur in cell } \\
\text { death-unrelated scenarios } \\
\text { Fluorogenic caspase substrates can be } \\
\text { stored for limited time }\end{array}$ & $\begin{array}{l}\text { Caspase activation is detected by } \\
\text { cell-permeant fluorogenic } \\
\text { substrates }\end{array}$ \\
\hline $\begin{array}{l}\text { Clonogenic } \\
\text { assays }\end{array}$ & $\begin{array}{l}\text { Determine the long-term fate of cells } \\
\text { Inexpensive and based on standard } \\
\text { laboratory equipment }\end{array}$ & $\begin{array}{l}\text { Require proliferating cells } \\
\text { Cannot discriminate between cell death } \\
\text { and senescence } \\
\text { Laborious and time consuming }\end{array}$ & $\begin{array}{l}\text { Widely used in cancer research to } \\
\text { evaluate the long-term effects of } \\
\text { radio- and chemotherapy }\end{array}$ \\
\hline HPLC & $\begin{array}{l}\text { Very-high sensitivity (as compared to IB, } \\
\text { IF and ELISA-based methods) } \\
\text { Rapid (as compared to IB) }\end{array}$ & $\begin{array}{l}\text { Dedicated technological platform } \\
\text { Requires trained personnel } \\
\text { Needs subcellular fractionation } \\
\text { Protocols may demand for extensive } \\
\text { optimization }\end{array}$ & $\begin{array}{l}\text { Applied to the detection of Cyt } c \\
\text { release }\end{array}$ \\
\hline ImageStream & $\begin{array}{l}\text { Allows for the simultaneous acquisition } \\
\text { from each flowing cell of both overall } \\
\text { fluorescence and of multiple } \\
\text { microphotographs }\end{array}$ & $\begin{array}{l}\text { Expensive technological platform } \\
\text { Unsuitable to study rare events } \\
\text { Automation of the analytical procedures } \\
\text { may be problematical }\end{array}$ & $\begin{array}{l}\text { Employed to discriminate among } \\
\text { live, apoptotic and necrotic cells, } \\
\text { as well as to measure apoptotic } \\
\text { index }\end{array}$ \\
\hline MS & $\begin{array}{l}\text { May provide a large amount of } \\
\text { experimental data (e.g., analysis of the } \\
\text { entire proteome released by mitochondria } \\
\text { undergoing MMP) } \\
\text { Compatible with quantitative applications }\end{array}$ & $\begin{array}{l}\text { Expensive technological platform } \\
\text { Requires qualified operators } \\
\text { Prolonged optimization of the protocols } \\
\text { may be necessary } \\
\text { Unsuitable for high-throughput applications }\end{array}$ & $\begin{array}{l}\text { Used to characterize cell death- } \\
\text { related changes in the proteome of } \\
\text { specific subcellular compartments }\end{array}$ \\
\hline NMR & $\begin{array}{l}\text { Allows for the identification of MOMP, } \\
\text { MPT and other scenarios of cell death } \\
\text { at a molecular level } \\
\text { Identify more complex cell death scenarios, } \\
\text { as those occurring in vivo }\end{array}$ & $\begin{array}{l}\text { Only on purified components } \\
\text { Highly expensive instrument that requires } \\
\text { trained personnel } \\
\text { Inappropriate for routine determinations }\end{array}$ & $\begin{array}{l}\text { The NMR properties of structured } \\
\text { water within mitochondria change } \\
\text { in distinct cell death-related } \\
\text { scenarios }\end{array}$ \\
\hline
\end{tabular}

Abbreviations: Cyt $c$, cytochrome $c$; ELISA, enzyme-linked immunosorbent assay; HPLC, high-pressure liquid chromatography; IB, immunoblotting; IF, (immuno)fluorescence microscopy; MMP, mitochondrial membrane permeabilization; MOMP, mitochondrial outer membrane permeabilization; MPT, mitochondrial permeability transition; MS, mass spectrometry; NMR, nuclear magnetic resonance

avoid false-negative and/or -positive results as well as gross misinterpretations, researchers should approach the study of cell death (as defined by the etymological recommendations recently provided by the NCCD) ${ }^{2}$ by bearing in mind the following two fundamental questions: (1) are cells truly dead, and if so, (2) by which subroutine did cell death occur? To answer the first question, investigators need to combine at least two distinct methods that assess end-stage cell death (e.g., LDH release and incorporation of exclusion dyes, in vitro), and perform, whenever possible, long-term survival assays to detect delayed cell death events (especially for postmitotic cells). In doing so, they will obtain a reliable, quantitative evaluation of cell death, which is a sine qua non for subsequent studies (see below).

Similarly, to characterize cell death in mechanistic terms (i.e., to answer the second question), at least two complementary, but methodologically unrelated, techniques should be employed to demonstrate the involvement of the same biochemical phenomenon. As an example, the activation of caspases may be indisputably proved by combining miniaturized fluorogenic assays with cytofluorometry- and/or immunofluorescence microscopy-based tests. As cell death is highly heterogeneous - however - the signaling pathways that lead to cell death may differ even across relatively similar experimental settings. Thus, it remains at each investigator's discretion to decide which are the most appropriate biochemical parameters that should be monitored for the mechanistic characterization of cell death in his/her experimental setup. As a final - but cardinal - note of caution, it should always be remembered that several cell death-related phenomena (e.g., activation of caspases, p53-dependent gene transactivation) also occur in cell death-unrelated settings (e.g., differentiation of several hematopoietic precursors, DNA repair). ${ }^{78,82}$ It is, therefore, crucial for researchers to answer the abovementioned questions in the correct order, to avoid the arguably worst mistake of all: investigating the mechanisms of cell death in the absence of cell death.

Acknowledgements. We declare no conflicting financial interests. This work was supported by a special grant from Ligue Nationale contre le Cancer (LNC), as well as grants by Agence Nationale de Recherche (ANR), Agence Nationale de Recherches sur le SIDA (ANRS), Institut National du Cancer (INCa), Cancéropôle llede-France, Fondation pour la Recherche Médicale (FRM), Sidaction (to GK) and the European Commission (Active p53, Apo-Sys, ApopTrain, DeathTrain, TransDeath, RIGHT). This work was supported by the NIH intramural program. SAA, JA, EA, EHB, NGB, MVB, DEB, JAC, MD, BDD, WSE, RAF, DRG, GH, JMH, DJK, SK, BL, SAL, EL, UMM, GN, MEP, HS, RJY and JY are supported by the National Institute of Health (NIH). HP is funded by the National Health and Medical Research Council (NHMRC). OK is the recipient of an EMBO Ph.D. fellowship. EM is funded by an ApopTrain Ph.D. student fellowship. DCR is a Wellcome Trust Senior Clinical Fellow.

1. Kroemer G, Galluzzi L, Brenner C. Mitochondrial membrane permeabilization in cell death. Physiol Rev 2007; 87: 99-163.

2. Kroemer G, Galluzzi L, Vandenabeele P, Abrams J, Alnemri ES, Baehrecke EH et al. Classification of cell death: recommendations of the Nomenclature Committee on Cell Death 2009. Cell Death Differ 2009; 16: 3-11. 
3. Northington FJ, Zelaya ME, O'Riordan DP, Blomgren K, Flock DL, Hagberg $\mathrm{H}$ et al. Failure to complete apoptosis following neonatal hypoxia-ischemia manifests as "continuum" phenotype of cell death and occurs with multiple manifestations of mitochondrial dysfunction in rodent forebrain. Neuroscience 2007; 149: 822-833.

4. Baehrecke EH. Autophagy: dual roles in life and death? Nat Rev Mol Cell Biol 2005; 6 505-510.

5. Kroemer G, Levine B. Autophagic cell death: the story of a misnomer. Nat Rev Mol Cell Biol 2008; 9: 1004-1010.

6. Berry DL, Baehrecke EH. Growth arrest and autophagy are required for salivary gland cell degradation in Drosophila. Cell 2007; 131: 1137-1148.

7. Hou YC, Chittaranjan S, Barbosa SG, McCall K, Gorski SM. Effector caspase Dcp-1 and IAP protein Bruce regulate starvation-induced autophagy during Drosophila melanogaster oogenesis. J Cell Biol 2008; 182: 1127-1139.

8. Mohseni N, McMillan SC, Chaudhary R, Mok J, Reed BH. Autophagy promotes caspasedependent cell death during Drosophila development. Autophagy 2009; 5: 329-338.

9. Nezis IP, Lamark T, Velentzas AD, Rusten TE, Bjorkoy G, Johansen T et al. Cell death during Drosophila melanogaster early oogenesis is mediated through autophagy. Autophagy 2009; 5: 298-302.

10. Maiuri MC, Zalckvar E, Kimchi A, Kroemer G. Self-eating and self-killing: crosstalk between autophagy and apoptosis. Nat Rev Mol Cell Biol 2007; 8: 741-752.

11. Boya $\mathrm{P}$, Gonzalez-Polo RA, Casares N, Perfettini JL, Dessen P, Larochette N et al. Inhibition of macroautophagy triggers apoptosis. Mol Cell Biol 2005; 25: 1025-1040.

12. Galluzzi L, Vicencio JM, Kepp O, Tasdemir E, Maiuri MC, Kroemer G. To die or not to die: that is the autophagic question. Curr Mol Med 2008; 8: 78-91.

13. Klionsky DJ, Abeliovich $\mathrm{H}$, Agostinis $\mathrm{P}$, Agrawal DK, Aliev G, Askew DS et al. Guidelines for the use and interpretation of assays for monitoring autophagy in higher eukaryotes. Autophagy 2008; 4: 151-175.

14. Gavrieli $Y$, Sherman $Y$, Ben-Sasson SA. Identification of programmed cell death in situ via specific labeling of nuclear DNA fragmentation. J Cell Biol 1992; 119: 493-501.

15. Sloop GD, Roa JC, Delgado AG, Balart JT, Hines III MO, Hill JM. Histologic sectioning produces TUNEL reactivity. A potential cause of false-positive staining. Arch Pathol Lab Med 1999; 123: 529-532.

16. Liang XH, Kleeman LK, Jiang HH, Gordon G, Goldman JE, Berry G et al. Protection against fatal Sindbis virus encephalitis by beclin, a novel Bcl-2-interacting protein. J Virol 1998; 72 : 8586-8596.

17. Terauchia S, Yamamotoa T, Yamashita K, Kataoka M, Terada H, Shinohara Y. Molecular basis of morphological changes in mitochondrial membrane accompanying induction of permeability transition, as revealed by immuno-electron microscopy. Mitochondrion 2005; 5: 248-254.

18. de Graaf AO, van den Heuvel LP, Dijkman HB, de Abreu RA, Birkenkamp KU, de Witte T et al. Bcl-2 prevents loss of mitochondria in CCCP-induced apoptosis. Exp Cell Res 2004; 299: $533-540$

19. de La Motte Rouge T, Galluzzi L, Olaussen KA, Zermati Y, Tasdemir E, Robert T et al. A novel epidermal growth factor receptor inhibitor promotes apoptosis in non-small cell lung cancer cells resistant to erlotinib. Cancer Res 2007; 67: 6253-6262.

20. Godlewski MM, Gajkowska B, Lamparska-Przybysz M, Motyl T. Colocalization of BAX with BID and VDAC-1 in nimesulide-induced apoptosis of human colon adenocarcinoma COLO 205 cells. Anticancer Drugs 2002; 13: 1017-1029.

21. Wang XM, Terasaki PI, Rankin Jr GW, Chia D, Zhong HP, Hardy S. A new microcellular cytotoxicity test based on calcein AM release. Hum Immunol 1993; 37: 264-270.

22. Poncet D, Boya P, Metivier D, Zamzami N, Kroemer G. Cytofluorometric quantitation of apoptosis-driven inner mitochondrial membrane permeabilization. Apoptosis 2003; 8 : 521-530

23. Abrams JM, White K, Fessler LI, Steller H. Programmed cell death during Drosophila embryogenesis. Development 1993; 117: 29-43.

24. Arama E, Steller H. Detection of apoptosis by terminal deoxynucleotidyl transferasemediated dUTP nick-end labeling and acridine orange in Drosophila embryos and adult male gonads. Nat Protoc 2006; 1: 1725-1731.

25. Robu ME, Larson JD, Nasevicius A, Beiraghi S, Brenner C, Farber SA et al. p53 activation by knockdown technologies. PLoS Genet 2007; 3: e78

26. Petit PX, Lecoeur H, Zorn E, Dauguet C, Mignotte B, Gougeon ML. Alterations in mitochondrial structure and function are early events of dexamethasone-induced thymocyte apoptosis. J Cell Biol 1995; 130: 157-167.

27. Galluzzi L, Zamzami N, de La Motte Rouge T, Lemaire C, Brenner C, Kroemer G. Methods for the assessment of mitochondrial membrane permeabilization in apoptosis. Apoptosis 2007; 12: 803-813.

28. Davis WP, Janssen YM, Mossman BT, Taatjes DJ. Simultaneous triple fluorescence detection of mRNA localization, nuclear DNA, and apoptosis in cultured cells using confocal scanning laser microscopy. Histochem Cell Biol 1997; 108: 307-311.

29. Macho A, Decaudin D, Castedo M, Hirsch T, Susin SA, Zamzami N et al. Chloromethyl-XRosamine is an aldehyde-fixable potential-sensitive fluorochrome for the detection of early apoptosis. Cytometry 1996; 25: 333-340.

30. Szilagyi G, Simon L, Koska P, Telek G, Nagy Z. Visualization of mitochondrial membrane potential and reactive oxygen species via double staining. Neurosci Lett 2006; 399 206-209.

31. Petronilli V, Miotto G, Canton M, Brini M, Colonna R, Bernardi P et al. Transient and longlasting openings of the mitochondrial permeability transition pore can be monitored directly in intact cells by changes in mitochondrial calcein fluorescence. Biophys $J$ 1999; 76 : 725-734

32. Wolter KG, Hsu YT, Smith CL, Nechushtan A, Xi XG, Youle RJ. Movement of Bax from the cytosol to mitochondria during apoptosis. J Cell Biol 1997; 139: 1281-1292.

33. Poncet D, Larochette N, Pauleau AL, Boya P, Jalil AA, Cartron PF et al. An anti-apoptotic viral protein that recruits Bax to mitochondria. J Biol Chem 2004; 279: 22605-22614.

34. Ostenfeld MS, Fehrenbacher N, Hoyer-Hansen M, Thomsen C, Farkas T, Jaattela M. Effective tumor cell death by sigma-2 receptor ligand siramesine involves lysosomal leakage and oxidative stress. Cancer Res 2005; 65: 8975-8983.

35. Groth-Pedersen L, Ostenfeld MS, Hoyer-Hansen M, Nylandsted J, Jaattela M. Vincristine induces dramatic lysosomal changes and sensitizes cancer cells to lysosome-destabilizing siramesine. Cancer Res 2007; 67: 2217-2225.

36. Kroemer G, Jaattela M. Lysosomes and autophagy in cell death control. Nat Rev Cancer 2005; 5: 886-897.

37. Kluck RM, Bossy-Wetzel E, Green DR, Newmeyer DD. The release of cytochrome from mitochondria: a primary site for Bcl-2 regulation of apoptosis. Science 1997; 275 $1132-1136$

38. Susin SA, Lorenzo HK, Zamzami N, Marzo I, Brenner C, Larochette N et al. Mitochondria release of caspase-2 and -9 during the apoptotic process. J Exp Med 1999; 189: 381-394.

39. Susin SA, Lorenzo HK, Zamzami N, Marzo I, Snow BE, Brothers GM et al. Molecular characterization of mitochondrial apoptosis-inducing factor. Nature 1999; 397: 441-446.

40. Criollo A, Galluzzi L, Maiuri MC, Tasdemir E, Lavandero S, Kroemer G. Mitochondrial control of cell death induced by hyperosmotic stress. Apoptosis 2007; 12: 3-18.

41. Goldstein J, Waterhouse N, Juin P, Evan G, Green D. The coordinate release of cytochrome $\mathrm{c}$ during apoptosis is rapid, complete and kinetically invariant. Nat Cell Biol 2000; 2: 156-162.

42. Patterson GH, Lippincott-Schwartz J. A photoactivatable GFP for selective photolabeling of proteins and cells. Science 2002; 297: 1873-1877.

43. Berman SB, Chen YB, Qi B, McCaffery JM, Rucker III EB, Goebbels S et al. Bcl-xL increases mitochondrial fission, fusion, and biomass in neurons. J Cell Biol 2009; 184 707-719.

44. Castedo M, Coquelle A, Vivet S, Vitale I, Kauffmann A, Dessen P et al. Apoptosis regulation in tetraploid cancer cells. EMBO J 2006; 25: 2584-2595.

45. Tamura $Y$, Simizu S, Osada $H$. The phosphorylation status and anti-apoptotic activity of $\mathrm{Bcl}-2$ are regulated by ERK and protein phosphatase $2 \mathrm{~A}$ on the mitochondria. FEBS Lett 2004; 569: 249-255.

46. Hsu YT, Youle RJ. Bax in murine thymus is a soluble monomeric protein that displays differential detergent-induced conformations. J Biol Chem 1998; 273: 10777-10783.

47. Tajeddine N, Galluzzi L, Kepp O, Hangen E, Morselli E, Senovilla L et al. Hierarchica involvement of Bak, VDAC1 and Bax in cisplatin-induced cell death. Oncogene 2008; 27 $4221-4232$.

48. Bursch W, Hochegger K, Torok L, Marian B, Ellinger A, Hermann RS. Autophagic and apoptotic types of programmed cell death exhibit different fates of cytoskeletal filaments J Cell Sci 2000; 113 (Pt 7): 1189-1198.

49. Seth R, Yang C, Kaushal V, Shah SV, Kaushal GP. p53-dependent caspase-2 activation in mitochondrial release of apoptosis-inducing factor and its role in renal tubular epithelial cell injury. J Biol Chem 2005; 280: 31230-31239.

50. Galluzzi L, Vitale I, Kepp O, Seror C, Hangen E, Perfettini JL et al. Methods to dissect mitochondrial membrane permeabilization in the course of apoptosis. Methods Enzymol 2008; 442: 355-374.

51. Troiano L, Ferraresi R, Lugli E, Nemes E, Roat E, Nasi M et al. Multiparametric analysis of cells with different mitochondrial membrane potential during apoptosis by polychromatic flow cytometry. Nat Protoc 2007; 2: 2719-2727.

52. Castedo M, Ferri K, Roumier T, Metivier D, Zamzami N, Kroemer G. Quantitation of mitochondrial alterations associated with apoptosis. J Immunol Methods 2002; 265: 39-47.

53. Zermati Y, Mouhamad S, Stergiou L, Besse B, Galluzzi L, Boehrer S et al. Nonapoptotic role for Apaf-1 in the DNA damage checkpoint. Mol Cell 2007; 28: 624-637.

54. Martin SJ, Reutelingsperger CP, McGahon AJ, Rader JA, van Schie RC, LaFace DM et al. Early redistribution of plasma membrane phosphatidylserine is a general feature of apoptosis regardless of the initiating stimulus: inhibition by overexpression of $\mathrm{Bcl}-2$ and $\mathrm{Abl}$. J Exp Med 1995; 182: 1545-1556.

55. Komoriya A, Packard BZ, Brown MJ, Wu ML, Henkart PA. Assessment of caspase activities in intact apoptotic thymocytes using cell-permeable fluorogenic caspase substrates. J Exp Med 2000; 191: 1819-1828.

56. Li J, Petrassi HM, Tumanut C, Masick BT, Trussell C, Harris JL. Substrate optimization for monitoring cathepsin C activity in live cells. Bioorg Med Chem 2009; 17: 1064-1070.

57. LeBel CP, Ischiropoulos $H$, Bondy SC. Evaluation of the probe $2^{\prime}, 7^{\prime}$-dichlorofluorescin as an indicator of reactive oxygen species formation and oxidative stress. Chem Res Toxico 1992; 5: 227-231.

58. Lecoeur H, Langonne A, Baux L, Rebouillat D, Rustin P, Prevost MC et al. Real-time flow cytometry analysis of permeability transition in isolated mitochondria. Exp Cell Res 2004; 294: 106-117.

59. Marzo I, Susin SA, Petit PX, Ravagnan L, Brenner C, Larochette $\mathrm{N}$ et al. Caspases disrupt mitochondrial membrane barrier function. FEBS Lett 1998; 427: 198-202.

60. Lagasse $E$, Weissman IL. bcl-2 inhibits apoptosis of neutrophils but not their engulfment by macrophages. J Exp Med 1994; 179: 1047-1052. 
61. Qu X, Zou Z, Sun Q, Luby-Phelps K, Cheng P, Hogan RN et al. Autophagy genedependent clearance of apoptotic cells during embryonic development. Cell 2007; 128 : 931-946.

62. Bradbury DA, Simmons TD, Slater KJ, Crouch SP. Measurement of the ADP:ATP ratio in human leukaemic cell lines can be used as an indicator of cell viability, necrosis and apoptosis. J Immunol Methods 2000; 240: 79-92.

63. Tasdemir E, Maiuri MC, Galluzzi L, Vitale I, Djavaheri-Mergny M, D'Amelio M et al. Regulation of autophagy by cytoplasmic p53. Nat Cell Biol 2008; 10: 676-687.

64. Vitale I, Galluzzi L, Vivet S, Nanty L, Dessen P, Senovilla L et al. Inhibition of Chk1 kills tetraploid tumor cells through a p53-dependent pathway. PLOS ONE 2007; 2 : e1337.

65. Baize S, Leroy EM, Georges-Courbot MC, Capron M, Lansoud-Soukate J, Debre P et al. Defective humoral responses and extensive intravascular apoptosis are associated with fatal outcome in Ebola virus-infected patients. Nat Med 1999; 5: 423-426.

66. Bonfoco E, Krainc D, Ankarcrona M, Nicotera P, Lipton SA. Apoptosis and necrosis: two distinct events induced, respectively, by mild and intense insults with N-methyl-D-aspartate or nitric oxide/superoxide in cortical cell cultures. Proc Natl Acad Sci USA 1995; 92 7162-7166.

67. Krysko DV, Vanden Berghe T, D'Herde K, Vandenabeele P. Apoptosis and necrosis: detection, discrimination and phagocytosis. Methods 2008; 44: 205-221.

68. Krysko DV, Vanden Berghe T, Parthoens E, D'Herde K, Vandenabeele P. Methods fo distinguishing apoptotic from necrotic cells and measuring their clearance. Methods Enzymol 2008; 442: 307-341.

69. Belzacq-Casagrande AS, Martel C, Pertuiset C, Borgne-Sanchez A, Jacotot E, Brenner C. Pharmacological screening and enzymatic assays for apoptosis. Front Biosci 2009; 14 3550-3562.

70. Blattner JR, He L, Lemasters JJ. Screening assays for the mitochondrial permeability transition using a fluorescence multiwell plate reader. Anal Biochem 2001; 295: 220-226.
71. Tao $Y$, Zhang $P$, Girdler F, Frascogna V, Castedo M, Bourhis $\mathrm{J}$ et al. Enhancement of radiation response in $\mathrm{p53}$-deficient cancer cells by the Aurora-B kinase inhibitor AZD1152. Oncogene 2008; 27: 3244-3255.

72. Wyllie AH. Glucocorticoid-induced thymocyte apoptosis is associated with endogenous endonuclease activation. Nature 1980; 284: 555-556.

73. George TC, Basiij DA, Hall BE, Lynch DH, Ortyn WE, Perry DJ et al. Distinguishing modes of cell death using the ImageStream multispectral imaging flow cytometer. Cytometry $A$ 2004; 59: 237-245.

74. Pouliquen D, Bellot G, Guihard G, Fichet P, Meflah K, Vallette FM. Mitochondrial membrane permeabilization produced by PTP, Bax and apoptosis: a 1H-NMR relaxation study. Cell Death Differ 2006; 13: 301-310.

75. Crouser ED, Gadd ME, Julian MW, Huff JE, Broekemeier KM, Robbins KA et al. Quantitation of cytochrome c release from rat liver mitochondria. Anal Biochem 2003; 317: 67-75.

76. Patterson SD, Spahr CS, Daugas E, Susin SA, Irinopoulou T, Koehler C et al. Mass spectrometric identification of proteins released from mitochondria undergoing permeability transition. Cell Death Differ 2000; 7: 137-144.

77. Obeid M, Tesniere A, Ghiringhelli F, Fimia GM, Apetoh L, Perfettini JL et al. Calreticulin exposure dictates the immunogenicity of cancer cell death. Nat Med 2007; 13: 54-61.

78. Galluzzi L, Joza N, Tasdemir E, Maiuri MC, Hengartner M, Abrams JM et al. No death without life: vital functions of apoptotic effectors. Cell Death Differ 2008; 15: 1113-1123.

79. Timmer JC, Salvesen GS. Caspase substrates. Cell Death Differ 2007; 14: 66-72

80. De Maria R, Zeuner A, Eramo A, Domenichelli C, Bonci D, Grignani F et al. Negative regulation of erythropoiesis by caspase-mediated cleavage of GATA-1. Nature 1999; 401: 489-493

81. Zermati Y, Garrido C, Amsellem S, Fishelson S, Bouscary D, Valensi F et al. Caspase activation is required for terminal erythroid differentiation. J Exp Med 2001; 193: 247-254.

82. Janicke RU, Sohn D, Schulze-Osthoff K. The dark side of a tumor suppressor: antiapoptotic p53. Cell Death Differ 2008; 15: 959-976. 